IZA DP No. 7846

Universal Child Care, Maternal Employment, and Children's Long-Run Outcomes:

Evidence from the U.S. Lanham Act of 1940

Chris M. Herbst

December 2013 


\title{
Universal Child Care, Maternal Employment, and Children's Long-Run Outcomes: Evidence from the U.S. Lanham Act of $\mathbf{1 9 4 0}$
}

\author{
Chris M. Herbst \\ Arizona State University \\ and IZA
}

Discussion Paper No. 7846

December 2013

\author{
IZA \\ P.O. Box 7240 \\ 53072 Bonn \\ Germany \\ Phone: +49-228-3894-0 \\ Fax: +49-228-3894-180 \\ E-mail: iza@iza.org
}

Any opinions expressed here are those of the author(s) and not those of IZA. Research published in this series may include views on policy, but the institute itself takes no institutional policy positions. The IZA research network is committed to the IZA Guiding Principles of Research Integrity.

The Institute for the Study of Labor (IZA) in Bonn is a local and virtual international research center and a place of communication between science, politics and business. IZA is an independent nonprofit organization supported by Deutsche Post Foundation. The center is associated with the University of Bonn and offers a stimulating research environment through its international network, workshops and conferences, data service, project support, research visits and doctoral program. IZA engages in (i) original and internationally competitive research in all fields of labor economics, (ii) development of policy concepts, and (iii) dissemination of research results and concepts to the interested public.

IZA Discussion Papers often represent preliminary work and are circulated to encourage discussion. Citation of such a paper should account for its provisional character. A revised version may be available directly from the author. 


\section{ABSTRACT}

\section{Universal Child Care, Maternal Employment, and Children's Long-Run Outcomes: Evidence from the U.S. Lanham Act of $1940^{1}$}

This paper provides a comprehensive analysis of the Lanham Act of 1940, a heavilysubsidized and universal child care program that was administered throughout the U.S. during World War II. I begin by estimating the impact of the Lanham Act on maternal employment using 1940 and 1950 Census data in a difference-in-difference-in-differences framework. The evidence suggests that mothers' paid work increased substantially following the introduction of the child care program. I then study the implications of the Lanham Act for children's long-run outcomes related to educational attainment, family formation, and labor market participation. Using Census data from 1970 to 1990, I assess well-being in a lifecycle framework by tracking cohorts of treated individuals throughout their prime working years. Results from difference-in-differences models suggest that the Lanham Act had strong and persistent positive effects on well-being, equivalent to a 0.36 standard deviation increase in a summary index of adult outcomes. In addition, a supplementary analysis of distributional effects shows that the benefits of the Lanham Act accrued largely to the most economically disadvantaged adults. Together, these findings shed light on the design of contemporary child care systems that balance the twin goals of increasing parental employment and enhancing child well-being.

JEL Classification: J13

Keywords: $\quad$ universal child care, maternal employment, long-run outcomes

Corresponding author:

Chris M. Herbst

School of Public Affairs

Arizona State University

411 N. Central Ave., Ste. 450

Phoenix, AZ 85004-0687

USA

E-mail: chris.herbst@asu.edu

\footnotetext{
${ }^{1}$ This paper was previously circulated under the title "The Long-Term Effects of Publicly Subsidized Child Care: Evidence from the Lanham Act of 1940." I am grateful to seminar participants at the University of Arizona's Department of Sociology and the University College London-University of Bergen Labor and Child Care Workshop, as well as conference participants at the Association for Public Policy Analysis and Management and the Southern Economic Association for helpful suggestions. I also thank Joanna Lucio, Erdal Tekin, Melissa Kearney, Magne Mostad, Tarjei Havnes, Gordon Dahl, Liz Washbrook, Lane Kenworthy, and Resul Cesar for their detailed comments. ChenYu Kao, Andrew Kao, Zoram Kaul, and Casey Boyd-Swan provided excellent research assistance.
} 
In what is today a nearly forgotten social experiment, the federal government subsidized nationwide child care for working mothers of young children during World War II. It was the first time in the nation's history that day care for children who were not poor was supported by public funds

-Geraldine Youcha, Minding the Children, 1995

\section{Introduction}

The U.S. federal government in response to the surge in women's employment administered a system of near-universal child care throughout World War II (WWII). Popularly known as the Lanham Act of 1940, the child care program was considered a temporary war emergency measure, aimed at providing children ages 0 to 12 with a safe environment so that mothers could contribute to the nation's war production effort. ${ }^{2}$ Federal Lanham Act grants were awarded to communities based on a demonstrated need for war-time child care; at its apex the program was administered in over 635 communities in every state except New Mexico (Stoltzfus, 2000). Although it operated for only a brief period-from 1943 to 1946 - the Lanham Act dispensed over \$1 billion (in 2012 dollars) for the construction and maintenance of child care facilities, to train and pay teachers, and to provide meal service.

The Lanham Act is widely considered a milestone in the history of U.S. child care policy, primarily because it was the first, and only, federally-administered program to serve children regardless of family income. Yet there is virtually no understanding of the program's implications for a number of policy-relevant outcomes, including maternal employment and long-run child wellbeing. Such evidence is increasingly important in light of President Obama's Preschool for All proposal, which would provide all low- and moderate-income four-year-olds with full-day prekindergarten. ${ }^{3}$ The President's plan reflects the twin traits of universal access and high-quality that

\footnotetext{
${ }^{2}$ The Lanham Act funded a variety of war-essential public works projects in addition to providing child care services. For brevity's sake, I refer to the child care program as the Lanham Act throughout the paper.

${ }^{3}$ The plan, funded through a federal-state cost sharing arrangement, provides pre-kindergarten access to all children at or below 200 percent of the federal poverty line, and calls for additional financial incentives to states that want to broaden the program to serve higherincome children. The President's proposal is similar to a recently released plan from the Senate HELP Committee establishing a formulabased pre-kindergarten program for low- and moderate-income children. States would initially spend up to 10 percent of their own money to match federal funds for the first two years, increasing to a 100 percent match by the eighth year. In addition, the Senate plan allows states to expand access to three year-olds, as well as use up to 15 percent of funds for infants and toddlers.
} 
have become synonymous with the Oklahoma, Georgia, and Boston preschool programs. Although these programs have been studied extensively, only short- to medium-run evidence is currently available (e.g., Cascio \& Schanzenbach, 2013; Fitzpatrick, 2008; Gormley \& Gayer, 2005; Weiland \& Yoshikawa, 2013). Conversely, evidence on the long-run impact of early childhood programs comes almost exclusively from highly-targeted interventions, including the Head Start, Perry Preschool, and Abecedarian programs (e.g., Deming, 2009; Ludwig \& Miller, 2007; Anderson, 2008). To my knowledge, the only evidence on the long-run impact of universal child care comes from a recent evaluation of the Norwegian system (Havnes \& Mogstad, 2011a). The goal of this paper, therefore, is to provide the first comprehensive analysis of a broadly-accessible, heavily subsidized child care program in the U.S. context.

The paper begins by estimating the impact of the Lanham Act on maternal employment. To do so, I combine 1940 and 1950 Decennial Census data with a difference-in-difference-in-differences (DiDiD) approach to study labor supply at the participation and hours-of-work margins. The identification strategy exploits the large cross-state variation in the generosity of Lanham Act expenditures, comparing the effect of increased child care funding across women with and without age-eligible children after reform versus before reform. I find that the Lanham Act generated sizable increases in maternal employment. The baseline DiDiD estimate implies that increasing states' Lanham Act spending from the bottom to the top quartile of the distribution-equivalent to raising spending from $\$ 22$ to $\$ 65$ per child-would produce a 4.3 percentage point increase in the employment rate for treated women. This estimate is about one-quarter of the treated group's prereform mean.

I then turn my attention to the paper's primary focus: to examine the impact of the Lanham Act on children's long-run outcomes related to educational attainment, family formation, and labor market participation. I utilize Decennial Census data between 1970 and 1990 to identify a set of treated cohorts, who were born between 1931 and 1946, as well as a set of comparison cohorts, who 
were born between 1947 and 1951. The use of three Census datasets enables me to trace the full lifecycle effects of the Lanham Act, starting when treated cohorts were in their mid-20s and extending to their late-50s. I identify the impact of the child care program in a difference-indifferences (DiD) framework, essentially comparing the difference in adult outcomes between treated and comparison cohorts born in states where Lanham Act spending was high with the difference for these groups where spending was low. I find that the Lanham Act had large positive effects on a variety of outcomes that persisted throughout adulthood. In particular, the baseline DiD estimates imply that increasing spending from the Lanham Act median ( $\$ 44$ per child) to the level of Georgia’s Pre-K program $(\$ 2,000$ per four-year-old) would generate a 0.36 standard deviation increase in a summary index of nine adult outcomes. This effect size is larger than that produced in Deming's (2009) analysis of Head Start and comparable to those in Anderson's (2008) study of the Perry and Abecedarian programs. In addition, an auxiliary analysis of the Lanham Act's distributional effects reveals that the benefits of the child care program accrued largely to the most economically disadvantaged adults.

As with all DiD designs, the analysis of adult outcomes must overcome two threats to its internal validity: (i) the presence of unobserved, contemporaneous shocks that differentially affected the outcomes of treated and comparison cohorts, and (ii) the possibility that the outcomes of individuals born in low- and high-spending states would have trended differently in the absence of the Lanham Act. The key concern regarding the first threat is the shock represented by the war, which catalyzed a large exodus of men from the labor market and produced potentially important changes in children's home environment. I attempt to control directly for any war-induced changes in labor markets and home-life by adding the state-level Armed Forces mobilization rate (defined as the fraction of men ages 18 to 44 who were drafted or enlisted for war) to the baseline DiD model. This variable has been used by others to proxy the outflow of men from the labor market and the increased pressure on women to leave home for paid work (Acemoglu et al., 2004; Goldin \& Olivetti, 2013). 
The DiD estimates are robust to including the mobilization rate. As will be shown, this is likely the case because the mobilization rate is not an important determinant of Lanham Act spending.

To test for differential outcome trends, I exploit the fact that individuals in the comparison cohorts are drawn from a (post-reform) period in which the Lanham Act no longer operated. Unlike most DiD designs, which rarely permit an exploration of outcome trends in the absence of reform, this study is able to do so because the Lanham Act was terminated abruptly in 1946. Given that the comparison cohorts include individuals born in the first five years after the program's termination (i.e., 1947 to 1951), I am able to test directly for common outcome trends between comparison group individuals born in low- and high-spending states. The tests provide strong evidence that the common trends assumption is satisfied. I also experiment with a placebo reform that keeps the Lanham Act turned on for some cohorts in the comparison group. Consistent with the trends' evidence, the estimated effect of the placebo is small in magnitude and never statistically significant.

Together, these findings contribute to well-established literatures exploring the impact of early childhood programs on parental employment and child outcomes. In addition, this paper complements an important body of work assessing the role of WWII in increasing women's labor supply. Although early work by Goldin (1991) suggests that the war was not a "watershed" event for American women, more recent papers by Acemoglu et al. (2004) and Goldin and Olivetti (2013) challenge this notion, finding that the war did indeed catalyze a long-run employment response, particularly among married women. Estimates from the latter papers are based on DiD designs that exploit the measure of Armed Forces mobilization described above. In order for the mobilization rate to capture the causal effect of WWII, it must be the case that no unobserved shocks occurred contemporaneously with men's entry into military service. The current study, however, points to one such policy shock - the introduction of universal child care through the Lanham Act - that had detectable employment effects several years after the war's end. Given that the Lanham Act is credited with reshaping women's views on paid work and institutional child care (Cohen, 2001), the 
program may be partially responsible for the long-run rise in female employment documented in Acemoglu et al. (2004) and Goldin and Olivetti (2013). Thus, an open question for future research is whether the watershed event represented by WWII was aided by another watershed: the U.S.'s first, and only, universal child care program.

The remainder of the paper proceeds as follows. The next section summarizes the relevant research on the impact of child care prices and programs on maternal employment and long-run child outcomes. Section III provides a detailed description of the Lanham Act. In particular, it summarizes the history and major design features of the program, provides insight into the characteristics of and quality in Lanham Act centers, and introduces the measure of Lanham Act spending used in the empirical analyses. Section IV is devoted to the analysis of maternal employment, while Section V implements the analysis of long-run outcomes. Finally, Section VI concludes.

\section{Relevant Child Care Literature}

\section{Maternal Employment}

Evidence on the relationship between child care programs and maternal work decisions comes from three sources: reduced form and structural studies of child care prices, reduced form studies of child care subsidy programs, and quasi-experimental evaluations of policy reforms. The most common methodological approach to estimating price effects includes a discrete choice participation equation with selection-corrected predicted hourly child care expenditures and wages as the key right-hand-side variables. Results from these studies consistently point to a negative relationship between child care costs and mothers' employment (Anderson \& Levine 2000; Blau \& Robbins 1991; Connelly \& Kimmel 2003; Herbst, 2010; Ribar 1992; Tekin 2007a). However, the range of estimated own-price elasticities is quite large: 0.06 to -1.36 . The second approach examines the impact of actual child care subsidy receipt on maternal employment. The most frequently studied program is the U.S.'s Child Care and Development Fund (CCDF), an employment-based subsidy system targeting low-income families. The empirical framework models the employment decision 
using subsidy receipt as the key explanatory variable. The evidence suggests that CCDF-funded child care subsidies have large positive effects on the employment of economically disadvantaged single mothers (Blau \& Tekin, 2007; Tekin, 2005, 2007b).

The final set of studies exploits geographic and temporal variation in the introduction of policy reforms (DiD designs) or birthday-based discontinuities in program exposure (IV or regression discontinuity designs). Regarding DiD studies, Baker et al. (2008) and Lefebvre and Merrigan (2008) evaluate the introduction of universal child care in Quebec, Canada, while Havnes and Mogstad (2011b) examine Norway's universal program. U.S.-based DiD studies include Cascio and Schanzenbach's (2013) analysis of universal pre-kindergarten programs in Oklahoma and Georgia, as well as Cascio's (2009) paper on the introduction of kindergartens throughout the 1960s and 1970s. Regarding the latter design, Gelbach (2002) and Fitzpatrick (2012) use children's quarterof-birth in the 1980 and 2000 Census, respectively, to instrument for kindergarten participation, while Fitzpatrick (2010) uses the discontinuity created by age-eligibility cut-offs to analyze the Georgia and Oklahoma pre-kindergarten programs. With the exception of the Canadian child care program, these interventions typically generate small employment effects that are applicable to specific sub-groups (e.g., unmarried mothers).

\section{Long-Run Child Outcomes}

As previously discussed, most long-run evidence comes from studies of targeted educationfocused programs or small-scale interventions. For example, Ludwig and Miller's (2007) analysis of Head Start exploits the discontinuity in local program allocations, finding positive effects on mortality and educational attainment. Deming's (2009) paper, based on a sibling fixed effects strategy, finds that Head Start participants scored 0.23 standard deviations higher on a summary index of eight young adult outcomes. Positive long-run effects have also been estimated for participants in the Chicago Child-Parent Centers (Reynolds et al., 2011), Infant Health and Development (McCormick et al., 2006), and Perry and Abecedarian (Anderson, 2008) programs. For 
example, Anderson's (2008) reanalysis of Perry and Abecedarian yields effect sizes of 0.35 (women) and -0.01 (men) for the former and 0.45 (women) and 0.31 (men) for the latter on indices of adult outcomes.

Although there is a large body of evidence on publicly-funded child care programs, most are targeted at important sub-populations or limited to analyses of short- and medium-run outcomes. For example, Baker et al. (2008) provide evidence on the short-run developmental effects of universal child care in Quebec, Canada, while Gupta and Simonsen (2010) and Black et al. (2012) provide medium-run evidence for the Danish and Norwegian systems, respectively. In the U.S., Herbst and Tekin $(2010 ; 2012)$ estimate the short-run impact of the CCDF, a subsidy program restricted to the working poor, while a large number of studies examine the short- and medium-run impact of prekindergarten programs, only some of which are universal (e.g., Barnett et al., 2013; Cascio \& Schanzenbach, 2013; Fitzpatrick, 2008; Gormley \& Gayer, 2005; Weiland \& Yoshikawa, 2013).

To my knowledge, the only evidence on the long-run impact of universal child care comes from Havnes and Mogstad's (2011a) study of the Norwegian system. The reform was phased-in between 1976 and 1979, expanding child care access for those ages three to six. Exploiting the differential growth in child care coverage across municipalities, the author's DiD estimates imply sizeable increases in educational attainment, reductions in welfare participation, and delayed childbearing for treated cohorts in their early-30s. The results also show that most of the benefits accrued to individuals from economically disadvantaged backgrounds.

\section{Background on the Lanham Act}

\section{History and Description}

Prior to World War II, the Works Project Administration (WPA) operated a number of 
Depression-era child care centers that provided jobs for unemployed teachers. ${ }^{4}$ The centers served largely low-income families, and their primary purpose was to facilitate parents' transition back into the workforce. With the U.S.'s entry into the war-and men's subsequent exit from the labor market - it became clear that large numbers of women were needed to bolster war production. Aided by the Rosie the Riveter campaign, the federal government urged women, even those with young children, to join the war effort. However, it also become clear that the nation's stock of WPA child care centers would be insufficient for absorbing the growing demand for institutional child care. Indeed, stories of children locked in cars adjacent to factories, chained to temporary trailer homes, and left in movie theaters quickly filled newspapers and eventually became the subject of Congressional hearings (Youcha, 1995; U.S. Senate, 1943).

In response, federal funding for child care was approved in August 1942 through the National Defense Housing Act of 1940, also known as the Lanham Act. The Lanham Act was not designed to support publicly-provided child care. It was intended to fund the construction and maintenance of infrastructure projects (e.g., water and sewer systems and sanitation facilities) deemed critical to the war effort, as well as community hospitals and schools (Stoltzfus, 2000). ${ }^{5}$ Nevertheless, the Federal Works Agency (FWA) was assigned responsibility for distributing Lanham Act child care funds despite protests from several child- and education-centric agencies, including the Children's Bureau and Office of Education (Riley, 1994). With the FWA in control, the program's intent was clear: to administer a system of temporary child care as a war expedient, not as a permanent expansion to the welfare state.

Federal funds for wartime child care services were available for the construction and maintenance of facilities, to train and pay teachers, and to handle all other operating expenses. To

\footnotetext{
${ }^{4}$ This discussion draws on numerous historical accounts of the Lanham Act. For more information, see Anderson (1981), Dratch (1974), Fousekis (2011), Riley (1994), Stoltzfus (2000), Tank (1980), Tuttle (1995), and Youcha (1995).

${ }^{5}$ An interesting historical aside: the Lanham Act ultimately funded child care because the phrase "public services" in the original legislation was reinterpreted to include child care provision. It occurred without Presidential action, Congressional debate, or an alteration of the original legislative language.
} 
access federal Lanham Act grants, communities in "war impact areas" had to show the FWA that they did not have sufficient resources to meet the surging child care demand. The term "war impact area" was a designation given to communities that were directly involved in the war production effort. ${ }^{6}$ Grants awarded by the FWA were matched by community contributions that were initially set at 50 percent of a project's total cost. However, in practice, widespread resource constraints limited the local contribution to one-third of all expenses. Most local funding came from parent copayments, initially set at $\$ 0.50$ per child per day and rising to $\$ 0.75$ in 1945 . $^{7}$

The first Lanham Act funds were distributed in July 1943. Although the program was scheduled to be terminated soon after Japan's surrender in September 1945, President Roosevelt funded the program until mid-1946, after protests from families and advocates claimed that child care services were needed until servicemen returned home from the war. Eligibility for Lanham Act subsidies was restricted to children ages 0 to 12 , although initially there was some reluctance to serving the very young (ages 0 to 2 ) and in some instances children as old as 16 were served. Children ages 0 to 5 were served in center-based, or nursery, environments, while those ages 6 to 12 were provided with before- and after-school care. Given that the Lanham Act sought to bolster war production, there was a maternal work requirement, although this appears to have been de facto as opposed to explicit. Families were eligible regardless of income level, making the Lanham Act a near-universal child care program. Finally, the consumer subsidy was generous; at the war's peak, parents were required to contribute $\$ 0.75$ (\$9.50 in 2012 dollars) per child per day. ${ }^{8}$

\section{Quality in Lanham Act Child Care Centers}

Lanham Act centers operated for long hours. The evidence suggests that they provided child

\footnotetext{
${ }^{6}$ For example, these communities contained defense contractors, industries manufacturing war-essential goods (e.g., textiles), and those involved in agricultural production.

${ }^{7}$ Federal and local funds were deployed for different purposes. Money from the former was used to build and maintain child care centers, train and pay workers, purchase all supplies, and cover the cost of all other operating expenses. Money from the latter was used to purchase food that was served to children.

${ }^{8}$ In addition, the subsidy was not means-tested, and the parent co-payment was not determined on a sliding scale, as is the case with contemporary child care subsidy systems.
} 
care services six days per week, during holidays (except Christmas), and throughout the summer (Anderson, 1981; Youcha, 1995). Yet the centers were also responsive to local needs. For example, some centers provided night-time and evening care to accommodate factories and airfields operating on 24-hour schedules, while others maintained seasonal programs. It was common for preschoolaged children to spend at least 12 hours per day in the center, usually on a 6am to 6pm schedule; school-aged children spent less time in care, typically for a few hours before and after school.

Anecdotal evidence suggests that preschool-aged children engaged in indoor and outdoor play; used educational materials such paints, clay, and musical instruments; and took regular naps. In addition, children were provided with hot lunches, a snack, and dinner if necessary. The recommended teacher-child ratio in Lanham Act centers was 10-to-1, and many centers abided by the recommendation. Programs for school-aged children included breakfast and dinner, outdoor activities, participation in music and drama clubs, library reading, and assistance with schoolwork. California centers were among the highest-quality: they had an explicit nutrition focus; children were given a medical exam; parents completed a developmental history; and teachers were provided with in-service training and college credit (Koshuk, 1947). On the other hand, low-quality was pervasive in other areas. For example, a child care center in Baltimore reportedly contained 80 children in one room (with as many bathrooms); prepared meals on a hot-plate; and required children to cross a highway in order to reach the playground (Anderson, 1981). Thus, variation in quality across states and localities was likely to be substantial.

There were few systematic evaluations during and immediately following the war of children and parents using Lanham Act centers. Perhaps the best evidence comes from a descriptive analysis of children attending two centers in Bellflower, California, located in Los Angeles County (Koshuk, 1947). The study examined administrative records generated by the centers on a sub-set of 500 
children and parents from 1944 to $1946 .{ }^{9}$ Results from this analysis are illuminating. Perhaps the biggest concern from critics of the Lanham Act was that long hours in institutional care might fray the mother-child relationship. However, parent reports of children's behavior and family relationships suggest that such concerns were premature. Upon departure from the center, only 5.2 percent of mothers reported that the child was less willing to "obey or cooperate with adults;" 0.6 percent claimed that the child became "less affectionate;" and 1.7 percent felt that family relations were "less close." In addition, analyses of the teacher observations indicate that children made reasonable progress in specific developmental domains. For example, over 80 percent of children made "excellent" or "good" mental progress, relative to their status at entry, and about 75 percent of children made "excellent" or "good" social progress. Finally, despite parents' initial skepticism about institutional care, fully 100 percent of mothers reported that the "child enjoyed nursery school," and 81 percent had a "generally favorable" opinion of "early childhood education."

\section{Measurement of the Lanham Act}

To estimate the impact of the Lanham Act on maternal employment and long-run outcomes, I create a measure of total state-level Lanham Act spending per child ages 0 to 12 . I create this measure by compiling annual child care expenditure data from a variety of Congressional committee hearing reports, as well as from the publication Annual Report, Federal Works Agency (U.S. Senate, 1943a, b; U.S. House of Representatives, 1945; Federal Works Agency, various years). These sources provide expenditure data for the 1943 calendar year and the 1945 and 1946 fiscal years. Therefore, my spending variable covers nearly the full period in which the Lanham Act operated. To create the denominator of the spending ratio, I estimate the population of white, non-Hispanic children (ages 0 to 12) in each state using the Integrated Public Use Microdata Series (IPUMS) of the

\footnotetext{
${ }^{9}$ In addition to collecting demographic information on families, the centers conducted medical exams and took developmental histories. Teachers observed and recorded children's behavior at regular intervals, and parents upon withdrawing a child were given a detailed exit interview.
} 
1940 U.S. Decennial Census (Ruggles et al., 2010). ${ }^{10}$ The spending variable is adjusted to reflect constant 2012 dollars.

Lanham Act spending in the average state totaled about \$58 per child ages 0 to12 (median: $\$ 39)$, with a minimum of $\$ 0$ in New Mexico and maximum of $\$ 264$ in California. The top five states are California (\$264), Washington (\$251), Oregon (\$162), Florida (\$141), and Arizona (\$140). The bottom five states include Pennsylvania (\$8), North Dakota (\$6), West Virginia (\$5), Idaho (\$3), and New Mexico (\$0). ${ }^{11}$ Figure 1 provides a state-by-state look at Lanham Act spending. Specifically, I assign each state to a spending quartile, and then color-plot the quartiles. A few observations are noteworthy. First, there is substantial variation in the geographic location of low- and high-spending states. For example, those in the top-half of the distribution include low-population Western (e.g., Arizona and Utah) and Southeastern (e.g., Mississippi and South Carolina) states, as well as highpopulation states in the Northeast (e.g., Connecticut and Maryland). Second, there is a reasonable amount of (political) ideological variation across the low- and high-spending states. Eighteen of the 38 states carried by Roosevelt in the 1940 Presidential election are in the bottom-half of the spending distribution, and three of the 10 states voting for Wendell Willkie - the losing candidate - are in the top-half of the distribution. Thus, it appears that Roosevelt neither rewarded states voting for him nor penalized states voting against him. Finally, Lanham Act spending by coastal states was consistently greater than their inland counterparts: eight of the top 10 states are on the coast. This is consistent with the location of most war production centers, as defined by the number of "war impact areas" in each state, because manufacturing firms near the coast could quickly move goods into overseas war theaters (U.S. Senate, 1943a). ${ }^{12}$

\footnotetext{
${ }^{10}$ Also excluded are those residing on farms and in institutions. I create alternative spending variables that use as the denominator the total state population (white, non-Hispanic) and the female population ages 25 to 59 (white, non-Hispanic). Estimates of the impact of the Lanham Act based on these measures are similar to those shown throughout the paper.

${ }^{11}$ Note that Alaska and Hawaii are excluded from this and the forthcoming descriptive analyses of the Lanham Act because they were not yet states.

${ }^{12}$ Coastal states contained about 17 areas, on average, designated as "war impact areas," compared to 11 in non-coastal states.
} 
Table 1 explores more formally the state-level determinants of Lanham Act spending by estimating a series of regressions of child care expenditures on several state characteristics. The first four columns test several geographic and institutional variables. Column (1), which includes a binary indicator for coastal states, confirms that such states spent significantly more (\$46) through the Lanham Act than non-coastal states. Column (2) includes a binary indicator for states voting for Willkie in the 1940 Presidential election. The coefficient is statistically insignificant, suggesting again that funding decisions were not politically motivated. Column (3) adds a control for the Armed Forces mobilization rate, defined as the proportion of men ages 18 to 44 in each state that were drafted or enlisted for war. ${ }^{13}$ This variable has been used by others to proxy the war-induced outflow of men from the U.S. labor market (Acemoglu et al., 2004; Goldin \& Olivetti, 2013). Its coefficient is also statistically insignificant, indicating that the demographic forces shaping war enlistments (and thus the labor market impact of the war) are independent of the forces driving demand for war-time child care.

The last three columns test a few demographic characteristics. These variables are calculated using the 1940 Decennial Census from IPUMS (Ruggles et al., 2010). To maximize war production, it is plausible that Lanham Act funds were distributed in a manner that favored states with higher levels of female educational attainment and employment. Columns (5) and (6) examine this by adding the average number of years of completed schooling by women and the female employment rate, respectively. ${ }^{14}$ The coefficient on both variables is positive and statistically significant, providing evidence in favor of skill-biased funding decisions. When both are included in the regression with the coastal state indicator, as shown in column (7), the female employment variable

\footnotetext{
${ }^{13}$ Data on state-level mobilization rates can be found here: http://economics.mit.edu/faculty/dautor/data/autacemly06. Alternatively, they are included in Table A.1 of a working paper version of Goldin and Olivetti's (2013) published paper. The paper can be accessed here: http://www.nber.org/papers/w18676.pdf?new_window=1.

${ }^{14}$ The measure of female educational attainment is the one used in Acemoglu et al. (2004), and can be accessed here: http://economics.mit.edu/faculty/dautor/data/autacemly06. All other measures were created by the author from the 1940 Census.
} 
becomes statistically insignificant. The coefficient on coastal location in this and the other combined regression in column (4) is statistically significant and of a similar magnitude.

In results not reported here, I examine several other state characteristics, including the fraction of individuals residing on farms, the fraction black, and the fraction of married women. These variables are rarely statistically significant, and they do not alter the coastal state effect. Together, results from Table 1 suggest that coastal location is arguably the most important determinant of Lanham Act child care funding. It will be important, therefore, to control for this and other time-invariant differences between states by including state fixed effects in all forthcoming analyses. Robustness checks adding many of the (pre-reform) state-level characteristics discussed above, including the Armed Forces mobilization rate, will also be conducted.

\section{Analysis of Maternal Employment}

\section{Data Description}

The dataset for the maternal employment analysis is crafted from the one percent IPUMS of the 1940 and 1950 U.S. Decennial Census (Ruggles et al., 2010). The sample includes white, nonHispanic women in their prime working years (ages 25 to 64). Black women are excluded because their employment rates were comparatively high before the war, and work behavior did not change much during the war. Sample women are retained regardless of their place of birth as well as the presence and number of children in the household. Not included in the analysis are women residing in group quarters (e.g., institutions) or on farms. It is also important to note that IPUMS data for the 1940 and 1950 Census do not include individuals residing in Alaska and Hawaii; thus, women from these states are not represented in the analysis. After pooling observations for both Census dates, the analysis sample is a repeated cross-section of 406,677 women (1940: 187,604; 1950: 219,073). ${ }^{15}$

\footnotetext{
${ }^{15}$ There are a few noteworthy differences between the sample criteria outlined here and those discussed in Acemoglu et al. (2004) and Goldin and Olivetti's (2013) analysis. Both papers omit women residing in Nevada (because it underwent large population changes in the war and post-war periods) and the District of Columbia (presumably because war mobilization data are not available); such women are
} 
I examine two employment outcomes related to the extensive and intensive margins of labor supply. I begin by exploring a binary indicator of employment status that equals unity if a given woman engaged in any paid labor during the Census-defined reference week. In 1940, the reference week was March 24 to 30 (the Census was conducted on April 1), while the reference week in 1950 was the "previous week" (the Census was conducted over longer time period). To be coded as employed, women must have worked at least one hour for pay or profit during the reference week, worked at least 15 hours as an "unpaid family worker," or had a job from which they were temporarily absent (e.g., due to illness or vacation). I then consider a measure of the total number of hours each woman was at work during the reference week. This variable has a top-code of 98 hours in both Censuses.

I identify the employment response to the Lanham Act in part by exploiting the program's age eligibility rules regarding children. Recall that the Lanham Act served women with children ages 0 to 12 . Therefore, I define the treated group — or those likely to be exposed to the Lanham Act - as women whose youngest child was in the 0 to 12 age range during the period in which the Lanham Act was in operation (1943 to 1946). Such children were ages four to 19 in the 1950 Census. Two sets of women comprise the comparison group, or those not likely to be exposed to the Lanham Act: (i) women whose youngest child was ages 13 to 17 during the program's operation, making these children ages 20 to 24 in the 1950 Census, and (ii) childless women ages 25 to 64 . Women in the former group were ineligible to receive child care because their children were above the age eligibility threshold, while those in the latter group were ineligible because they did not have children in the first place. ${ }^{16}$ Identical sets of women in the treated and comparison groups were identified in

included in the current paper. In addition, while Acemoglu et al. (2004) retain women born outside the U.S., Goldin and Olivetti's (2013) omit these women. I follow Acemoglu et al. (2004) and do not apply a place-of-birth criterion on the sample. Approximately 87 percent of the women in my analysis sample are U.S. born. Goldin and Olivetti (2013) additionally restrict the sample to women ages 25 to 44 , and the subset of married women to those involved in their first marriage. I make no such marriage requirement in this paper.

${ }^{16}$ I conduct a series of robustness checks that include, in succession, only one of the two groups in the comparison group. Results from both sets of analyses are similar to those reported in the paper. 
the 1940 Census, making this the pre-reform period (the 1950 Census is designated as the postreform period), thereby providing another source of identifying variation.

Table 2 displays summary statistics for the characteristics of women in the treated and comparison groups, before and after the implementation of the Lanham Act. Treated women tend to be slightly younger, on average, than their counterparts in the comparison group. In addition, they are more likely to be married and to have no more than a high school degree. Given that the comparison group includes childless women, it is not surprising that the treated group is substantially more likely to have children residing in the household.

The triple differences model will be introduced formally in the next section, but suffice it to say that the model is identified in part by comparing the change in each employment outcome for the treated and comparison groups before and after the Lanham Act. Such a comparison might be problematic if these groups experienced differential changes in the demographic characteristics presented in Table 2. A cursory look at the means indicates that, fortunately, women in both groups underwent similar changes between 1940 and 1950; the one exception appears to be place-of-birth, in which treated women became 7.4 percentage points more likely to be U.S. born. In results not reported here, I confirm the uniformity in the demographic trends by estimating simple DiD regressions of each characteristic on an indicator for treatment group status, an indicator for the postreform period, an interaction between the two, and the remaining controls listed in Table $2 .{ }^{17}$ Importantly, the DiD estimate is small and statistically insignificant in the models for marital status and educational attainment, and it implies substantively minor relative changes in age (DiD estimate: -1.58), the fraction U.S. born (DiD estimate: 0.034), and the fraction residing in metropolitan areas (DiD estimate: -0.022).

\footnotetext{
${ }^{17}$ That is, the following regression is estimated: $Y_{\text {ist }}=\beta_{1}$ treated $_{\text {ist }}+\beta_{2}$ post $_{\mathrm{t}}+\beta_{3}\left(\right.$ treated $_{\text {ist }} \times$ post $\left._{\mathrm{t}}\right)+\mathbf{Z}^{\prime} \psi+\mu_{\text {ist }}$
} 


\section{Empirical Specification}

To estimate the impact of the Lanham Act on maternal employment, I utilize a difference-indifference-in-differences (DiDiD) estimator. As its name suggests, the model exploits three sources of variation in the data: (i) the program's age eligibility rule, which stipulated that women with children ages 0 to 12 could receive child care; (ii) geographic (i.e., cross-state) variation in the generosity of Lanham Act expenditures; and (iii) temporal variation in exposure, defined by distinct pre- and post-reform periods. Together, these sources of variation lead to the following empirical model:

(1) $Y_{\text {ist }}=\alpha_{\text {ist }}+\beta_{1}$ post $_{\mathrm{t}}+\beta_{2}$ lanham $_{\mathrm{s}}+\beta_{3}\left(\right.$ treated $_{\mathrm{ist}} \times$ post $\left._{\mathrm{t}}\right)+\beta_{4}\left(\right.$ treated $_{\mathrm{ist}} \times$ lanham $\left._{\mathrm{s}}\right)+$

$$
\beta_{5}\left(\text { post }_{\mathrm{t}} \times \text { lanham }_{\mathrm{s}}\right)+\beta_{6}\left(\text { treated }_{\mathrm{ist}} \times \text { post }_{\mathrm{t}} \times \text { lanham }_{\mathrm{s}}\right)+\mathbf{Z}^{\prime} \psi+v_{\mathrm{s}}+\mu_{\mathrm{ist}}
$$

where $Y$ is an employment outcome for woman $i$ in state $s$ and year $t$. As previously stated, the employment outcome refers to the binary indicator of employment status or the measure of weekly hours-of-work. The variable post is a binary indicator that equals unity for observations drawn from the 1950 Census (and zero for observations in the 1940 Census), while treated is a binary indicator that equals unity if the $i^{\text {th }}$ woman's youngest child was ages 0 to 12 during the Lanham Act's operation (and zero for women in the comparison group). The variable lanham is the measure of state-level Lanham Act spending per child ages 0 to 12 . The vector given by $\mathbf{Z}^{\prime}$ is a set of contemporaneous demographic controls, including marital status (six dummy variables), educational attainment (21 dummy variables), a binary indicator for U.S. born, and metropolitan residence (four dummy variables). ${ }^{18}$ Also included in (1) is a set of state-of-residence fixed effects $\left(v_{\mathrm{s}}\right)$ to control for permanent differences across states that may be correlated with Lanham Act spending, as well as a

\footnotetext{
${ }^{18}$ Information on educational attainment is not reported in the full 1950 Census. Rather, the information was gathered only for "sample line" adults who completed the full Census questionnaire. I retain these non-sample line individuals in the analysis by creating a binary indicator that equals unity for those coded "N/A or no schooling" on the 1950 IPUMS variable educd.
} 
full set of age fixed effects $\left(\alpha_{\mathrm{i}}\right) .{ }^{19}$ Equation (1) is estimated using ordinary least squares (OLS) regression, and the standard errors are adjusted for arbitrary forms of heteroskedasticity as well as state-level clustering.

The coefficient of interest is $\beta_{6}$, which provides the DiDiD estimate of the effect on maternal work activity of an increase in Lanham Act spending for treated relative to comparison group women, after versus before reform. It is important to be clear about what $\beta_{6}$ captures. Given that the post-reform outcomes are observed in 1950 - approximately three years after the Lanham Act was terminated $-\beta_{6}$ reflects the medium-run employment response to the child care program. It is beyond the scope of this study to examine longer-run outcomes, and to my knowledge there are no data available that would permit an analysis of the short-run impact of the Lanham Act. In addition, $\beta_{6}$ is interpreted as the intent-to-treat (ITT) effect of the Lanham Act. As such, it captures the reform effect on at least two groups of women with age-eligible children. First, there is the direct effect of the child care reform on mothers who used Lanham Act centers during the war. For some of these women, the short-run increase in employment translated into a longer-run response. Second, there is the indirect effect on women who did not use Lanham Act centers. As previously stated, the Lanham Act shifted women's views regarding institutional child care; in turn this cultural shift may have catalyzed some to combine work with non-parental care after the program was terminated.

As with all DiD designs, the model specified in (1) must overcome two key threats to the unbiasedness of $\beta_{6}$. The first threat is the presence of unobserved, contemporaneous shocks that may have differentially affected maternal employment across states spending different amounts on child care. The obvious concern in this context is the shock represented by the war, which by itself produced a sizeable employment response among women (Acemoglu et al., 2004; Goldin \& Olivetti, 2013). I do several things to disentangle the war's effect on employment from that of the Lanham

\footnotetext{
${ }^{19}$ In robustness checks, I replace the age fixed effects $\left(\alpha_{\mathrm{i}}\right)$ with an indicator for treated. I also estimate models that include the age fixed effects and treated simultaneously. The DiDiD results are robust to these alternative specifications.
} 
Act. My primary strategy, as shown in (1), is to interact post and lanham with treated; in doing so I compare the effect of Lanham Act spending across two groups women (i.e., treated and comparison group women) whose labor supply was arguably influenced in the same manner by the war, but only one of these groups (the treated group) was influenced by the child care program. ${ }^{20}$ Another strategy is to control directly for any war-driven changes in employment. I do so in a robustness check that adds the state-level Armed Forces mobilization rate to (1). As previously discussed, this variable proxies the outflow of men from the labor market, and the rising need for female workers (Acemoglu et al., 2004; Goldin \& Olivetti, 2013).

The second threat to the validity of the DiDiD estimate, $\beta_{6}$, is the possibility that states with different preexisting trends in maternal employment pursued Lanham Act funding more or less aggressively. Alternatively, the federal government might have made child care funding decisions by considering longstanding differences in the stock of human capital between states. Indeed, the regression results presented in Table 1 indicate that the federal government may have favored states with higher levels of educational attainment. Once again, I use the interaction of post and lanham with treated as the primary tool for handling the non-random assignment of child care funds to states. In particular, the three-way interaction should purge the effect of any differential employment trends (across states that received different levels of funding) because childless women and those with older children were not eligible to receive child care. I also conduct a series of robustness checks that add to (1) a number of pre-reform state-level characteristics, including the female employment rate, average female educational attainment (in years), the fraction black, and the fraction of individuals residing on farms. These variables are estimated from the 1940 Census, and should help to control

\footnotetext{
${ }^{20}$ Indeed, the evidence presented in Goldin and Olivetti (2013) shows that WWII influenced the labor supply of a fairly diverse group of women. Various specifications show that married women, both with and without children, and unmarried women experienced an increase in employment following WWII. The employment gains, however, appear to be concentrated among women with higher levels of education.
} 
for preexisting trends in employment that may be correlated with Lanham Act spending differences across states.

\section{DiDiD Estimation Results}

Table 3 provides a descriptive look at the change in outcomes between 1940 and 1950 experienced by treated and comparison group women. Approximately 16 percent of treated women were employed in 1940, compared 40 percent among those in the comparison group, producing an employment gap of 24 percentage points. However, this gap narrowed to about 20 percentage points by 1950 , implying a simple $\mathrm{DiD}$ estimate of 4.4 percentage points. This estimate is about one-quarter of the pre-reform mean for the treated group (0.159). Treated women experienced a similar increase in work behavior at the intensive margin: both groups witnessed an increase in weekly hours of work between 1940 and 1950, but the increase was larger for women in the treated group. Treated women worked 10.2 fewer hours per week in the pre-reform period, a gap that fell to 8.3 hours after reform. The DiD estimate therefore implies that treated women increased their weekly hours of work by nearly two hours. ${ }^{21}$

Although the results in Table 3 are suggestive of a positive employment response to the Lanham Act, the simple DiD estimates do not take full advantage of the variation in the data, namely omitting the substantial cross-state variation in Lanham Act spending. Therefore, Table 4 presents results from the DiDiD model outlined in (1), which exploits all three sources of identifying variation. Columns (1) and (2) provide estimates for the binary indicator of employment, and columns (3) and (4) provide those for weekly hours of work. The odd-numbered columns present the unconditional results, leaving out the demographic controls and state fixed effects, while the evennumbered columns present the full specification.

\footnotetext{
${ }^{21}$ The DiD estimate in an hours-of-work specification that excludes non-workers (i.e., those working zero hours) is smaller, implying a 0.33 -hour increase for treated women.
} 
The DiDiD estimates in Table 4 continue to show a positive effect of the Lanham Act at both work margins. Looking at the extensive margin, the baseline estimate [column (2)] implies that a one-dollar increase in Lanham Act spending (per child ages 0 to 12) led to a 0.1 percentage point increase in the employment rate. One way to interpret this estimate is to calculate the change in employment when the average treated woman is moved from a low- to a high-spending state. For example, states in the bottom quartile of the distribution spent approximately $\$ 22$ per child, while those in the top quartile spent about $\$ 65$ per child. Applying these figures to the DiDiD estimate implies that a move from the bottom to the top quartile of Lanham Act spending would generate a 4.3 percentage point increase in the employment rate for treated women. This estimate is about onequarter of the pre-reform mean for the treated group. A similar story emerges in the models examining labor supply at the intensive margin. The baseline DiDiD estimate [column (4)] suggests that a one-dollar increase in Lanham Act spending raised weekly hours of work by 0.04 hours. In other words, moving the average treated woman from the bottom to the top quartile of Lanham Act spending would generate an additional 1.9 hours of work per week. This response is similarly sizeable, as it is about one-third of the pre-reform mean for the treated group.

To probe the robustness of the results, Panel A of Table 5 estimates separate employment models that add a control for the state-level Armed Services mobilization rate as well as controls for states' pre-reform demographic characteristics. Each variable is interacted with treated and post, so that the coefficient can be interpreted as the differential effect of a given state characteristic across treated and comparison group women, after versus before reform. As shown in the first row, adding the mobilization rate does not alter the estimated effect of the Lanham Act. Interestingly, the coefficient on the mobilization rate is statistically insignificant in both employment models. The second row adds four pre-reform state characteristics (i.e., female employment rate, average female educational attainment in years, the fraction black, and the fraction of individuals residing on farms) 
that are intended to control for differential time trends in the employment outcomes in the absence of the Lanham Act. Inclusion of these controls also does not change the effect of the Lanham Act.

Panel B of Table 5 examines a number of important sub-groups, as defined by the age of the youngest child and the age, marital status, and educational attainment of the woman. As shown in the first two rows, treated women with younger children (ages 0 to 5) were more responsive to the Lanham Act than those with older children (ages 6 to 12). This pattern is consistent with the contemporary literature estimating the labor supply effects of child care prices and subsidies (Anderson \& Levine, 1998; Baker et al., 2008). Given these results, it is not surprising that younger women (ages 25-44) were also more responsive to the Lanham Act than older women (ages 45-64), as presented in rows three and four. Acemoglu et al.'s (2004) work similarly finds that war mobilization had a larger impact on the employment of younger women. The remaining results in Table 5 reveal smaller differences by marital status and educational attainment. That lower- and higher-skilled women responded nearly identically to the Lanham Act is intriguing in light of the Acemoglu et al. (2004) and Goldin and Olivetti (2013) papers. A key finding in both is that war mobilization-effects were concentrated on higher-skilled women, while having virtually no effect on the employment of the less-skilled.

\section{Lifecycle Analysis of Long-Run Outcomes}

\section{Data Description}

To examine the long-run impact of the Lanham Act, I use 1970 (one percent), 1980 (five percent), and 1990 (five percent) Decennial Census data from the IPUMS (Ruggles et al., 2010). I constrain the analysis to white, non-Hispanic individuals who were born within the continental U.S., and who were not residing in group quarters (e.g., institutions). I drop individuals for whom information on state of birth is not available, since Lanham Act spending data and other state-level variables cannot be merged to them. As will be explained in more detail below, I restrict the sample to individuals meeting year-of-birth criteria; this ensures that adults assigned to the treated group 
were (as children) age-eligible for child care when the Lanham Act was administered. The analyses are based on 405,952 observations in the 1970 Census, 2,215,767 observations in the 1980 Census, and 2,244,721 observations in the 1990 Census.

As shown in Table 6, I examine nine outcomes organized around adults' educational attainment (two outcomes), family formation (two outcomes), and labor market and program participation (five outcomes). To analyze educational attainment, I create a binary indictor that equals unity if a given individual did not complete high school and another indicator that equals unity if an individual completed at least a bachelor's degree. Regarding family formation, I examine an indicator for whether an individual is married (irrespective of the spouse's presence in the household) as well as an indicator for whether an individual is an unmarried parent. To be classified as such, the individual must be divorced, separated, widowed, or never married and have at least one own-child of any age residing in the household. As for the labor market domain, I examine a binary indicator of employment status that equals unity if a given individual engaged in any paid labor during the reference week. I also create an indicator of full-time employment, defined as working at least 35 hours during the reference week. The Census' retrospective questions on labor market activity and benefit receipt provide the foundation for the last three outcomes: a binary indicator for any paid labor during the previous calendar year; total pre-tax wage and salary income in the previous year; and a binary indicator for whether an individual received public assistance in the previous year. Public assistance is the sum of income from Supplemental Security Income (SSI), Aid to Families with Dependent Children (AFDC), and General Assistance (GA).

Given the large number of outcomes, all of which are observed at each Census date (for a total of 27 outcomes), I follow Deming (2009) and construct a summary index of each set of nine outcomes in the 1970, 1980, and 1990 Censuses (for a total of three outcomes). I normalize the individual outcomes to have a mean of zero and a standard deviation of one. After reversing the signs on a few-so that positive values indicate an improvement in well-being-I create a new variable 
representing the mean score of the normalized outcomes. Thus, higher values on the summary index imply better adult outcomes, on average, in the education, family formation, and labor market domains. This approach is advantageous because the effect sizes estimated here can be compared with those from Deming's (2009) analysis of Head Start and Anderson's (2008) reevaluation of the Perry and Abecedarian programs. Nevertheless, in auxiliary analyses, I present results from regressions of the nine individual outcomes at each Census date.

To identify the impact of the Lanham Act on adult outcomes, I estimate a DiD model similar in spirit to Havnes and Mostad (2011a). In particular, I draw comparisons of the adult outcome indices between cohorts exposed and not exposed to the Lanham Act as children, once again taking advantage of the large cross-state variation in the generosity of Lanham Act expenditures. Recall that the child care program operated during the period 1943 to 1946 , with eligibility extending to children ages 0 to 12 . Therefore, treated cohorts - defined as individuals who were age-eligible for the child care program for at least one year-were born between 1931 and 1946. These cohorts were ages 24 to 39 in the 1970 Census, ages 34 to 49 in the 1980 Census, and ages 44 to 59 in the 1990 Census. $^{22}$ Thus, by measuring adult outcomes for these cohorts at three Census dates, this study is able to trace the full lifecycle effects of the Lanham Act. To construct a comparison group of individuals not exposed to the Lanham Act, I include cohorts born in the first five years after the Lanham Act was terminated. Specifically, these individuals were born during the period 1947 to 1951, making them ages 19 to 23 in the 1970 Census, ages 29 to 33 in the 1980 Census, and ages 39 to 43 in the 1990 Census. $^{23}$

\section{Empirical Specification}

The DiD model exploits two sources of variation: (i) the Lanham Act's age eligibility rule,

\footnotetext{
${ }^{22}$ Individuals in the treated cohorts were exposed to the Lanham Act for differing numbers of years-depending on the year of birth. For example, an individual born in 1931 was 12 years-old in 1943; thus, this person was exposed to the Lanham Act for only one year. On the other hand, individuals born during the period 1934 to 1943 were exposed to the Lanham Act for all four years of its operation.

${ }^{23}$ Therefore, the sample is restricted to include individuals ages 19 to 39 in the 1970 Census, ages 29 to 49 in the 1980 Census, and ages 39 to 59 in the 1990 Census.
} 
which, in conjunction with individuals' year of birth, creates the treated and comparison cohorts described above; and (ii) geographic (i.e., cross-state) variation in the generosity of Lanham Act expenditures. These sources of variation are used to estimate the following regression model:

(2) $Y_{\text {its }}=\beta_{1}$ treated $_{\text {its }}+\beta_{2}$ lanham $_{\mathrm{s}}+\beta_{3}\left(\right.$ treated $_{\mathrm{its}} \times$ lanham $\left._{\mathrm{s}}\right)+\mathbf{Z}^{\prime} \psi+\gamma$ fob $_{\mathrm{s}}+\mathrm{v}_{\mathrm{s}}+\mu_{\mathrm{ist}}$,

where $Y$ is the outcome summary index for person $i$ in cohort $t$ and state-of-birth $s$. The variable treated is a binary indicator that equals unity if a given adult was exposed to the Lanham Act as a child (i.e., born during the period 1931 to 1946), and zero if the adult was not exposed to the program (i.e., born during the period 1947 to 1951$).{ }^{24}$ The variable lanham is the measure of state-level Lanham Act spending per child ages 0 to 12. It is merged to individuals based on the state-of-birth reported in the Census. The vector given by $\mathbf{Z}^{\prime}$ includes a number of demographic controls such as gender, farm residence, and region of residence (14 dummy variables). Also included here is a proxy for individuals' mobility, defined as a binary indicator for whether the state-of-residence (at the time the Census was taken) and the state-of-birth are the same. The variable mob is the state-level Armed Forces mobilization rate. Finally, (2) includes a set of state-of-birth fixed effects $\left(v_{\mathrm{s}}\right)$. The model is estimated separately on the 1970, 1980, and 1990 Censuses. Standard errors are adjusted for arbitrary forms of heteroskedasticity as well as state-level clustering.

The impact of the Lanham Act is given by the coefficient $\beta_{3}$, which is interpreted as the effect of increased child care spending for adults in treated cohorts relative to adults in the comparison cohorts. This estimate is conceptually equivalent to a comparison of the difference in outcomes between treated and comparison cohorts born in high-spending states with the difference for these groups born in low-spending states. To be interpreted as causal, the estimation of $\beta_{3}$ must overcome the same identification challenges as in the maternal employment analysis: (i) the presence of unobserved, contemporaneous shocks (e.g., the war) that may differentially affect adult outcomes

\footnotetext{
${ }^{24}$ In robustness checks, I replace treated with a full set of age fixed effects. Results from this specification are virtually identical to those presented here.
} 
across states spending different amounts through the Lanham Act, and (ii) the possibility that adult outcomes for individuals born in high- and low-spending states would have trended differently in the absence of the Lanham Act.

The primary strategy for purging $\beta_{3}$ of any war-induced changes in adult outcomes is to add the state-level Armed Forces mobilization rate ( $m o b)$ to (2). I also add to the baseline model a set of state-of-birth fixed effects $\left(v_{s}\right)$ to capture the unobserved, permanent differences across states that may be correlated with Lanham Act spending. To test whether the common trends assumption holds, I exploit the fact that the comparison cohorts are drawn from a (post-reform) period in which the Lanham Act no longer operated. Unlike most DiD designs, which rarely permit an exploration of outcome trends in the absence of reform, this study is able to do so because the Lanham Act was terminated abruptly in 1946. Given that the comparison cohorts include individuals born between 1947 and 1951, I am able to test explicitly whether there are common outcome trends between comparison individuals born in low- and high-spending states.

This test is implemented by estimating the following regression model separately for the 1970, 1980, and 1990 Censuses:

(3) $Y_{\text {its }}=\beta_{1}\left(\right.$ lanham $Q 1_{\mathrm{s}} \times$ trend $)+\beta_{2}\left(\right.$ lanhamQ2 $2_{\mathrm{s}} \times$ trend $)+\beta_{3}\left(\right.$ lanhamQ $3_{\mathrm{s}} \times$ trend $)+$

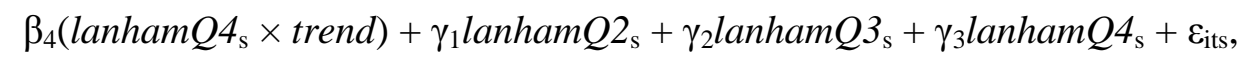

where $Y$ is the outcome summary index for person $i$ in cohort $t$ and state-of-birth $s$. The variables lanhamQ1, lanhamQ2, lanhamQ3, and lanhamQ4 are binary indicators that equal unity for individuals born in the first, second, third, and fourth quartiles, respectively, of the Lanham Act spending distribution. The variable trend counts from one to five for comparison group individuals born between 1947 (i.e., the first post-reform year) and 1951 (i.e., the fifth post-reform year). ${ }^{25}$ The

\footnotetext{
${ }^{25}$ In the analysis of the 1970 Census, for example, a value of one is assigned to individuals age 23; a value of two is assigned to individuals age 22; a value of three is assigned to individuals age 21; a value of four is assigned to individuals age 20; and a value of five
} 
coefficients $\beta_{1}, \beta_{2}, \beta_{3}$, and $\beta_{4}$ capture the adult outcome trends for comparison cohorts at each spending quartile of the Lanham Act. Consistency in the sign and magnitude of each coefficient provides evidence in support of the common trends assumption.

Table 7 presents results from (3). Columns (1) through (3) show the estimated comparison cohort trends for the 1970, 1980, and 1990 Censuses, respectively, along with the standard errors (in parentheses). Overall, the results provide strong evidence that the common trends assumption is satisfied. The coefficient on the trend variable is negative at each spending quartile, suggesting that outcomes for each subsequent cohort worsened slightly irrespective of how much Lanham Act spending occurred in the state-of-birth. Equally important is that the magnitude of the reduction in adult outcomes is similar at each spending quartile. In results not reported here, I estimate versions of (3) that replace the outcome summary index with the (nine) individual adult outcomes. In 20 of the 27 models estimated, all four quartile-trend coefficients take the same sign. In two of the models with inconsistent signs, tests of the null hypothesis of equal trend coefficients cannot be rejected at conventional levels. Thus, it appears that the common trends assumption applies to a broad swath of the individual outcomes as well.

Despite the evidence presented in Table 7, I conduct a number of robustness checks intended to further bolster confidence that the DiD framework satisfies the common trends assumption. First, I add to (2) a number of pre-reform state-level characteristics, including the female employment rate, average female educational attainment (in years), the fraction black, and the fraction of individuals residing on farms. As with the maternal employment analysis, the intent here is to control for potentially important state-level determinants of Lanham Act spending that, even in the absence of reform, may catalyze differential trends in the adult outcomes. The baseline DiD estimates are robust to the inclusion of these additional controls. Second, I implement a placebo reform that "turns on"

is assigned to individuals age 19. In the 1980 Census, values of one to five are assigned to individuals ages 33 to 29 . Finally, in the 1990 Census, values of one to five are assigned to individuals ages 43 to 39 . 
the Lanham Act for some cohorts in the comparison group. If the adult outcomes follow a similar time path in low- and high-spending states, then the estimated effect of the placebo reform should be statistically insignificant. Consistent with the trends' evidence presented in Table 7, I find that the placebos are small in magnitude and never statistically significant.

\section{Baseline DiD Estimation Results}

The main results from the DiD analysis of adult outcomes are shown in Figures 2 through 4 and in Table 8. The figures provide the intuition underlying the DiD regression results. In particular, they plot for each age the mean value on the outcome summary index, both for individuals born in low-spending (i.e., bottom decile) and high-spending (i.e., top decile) Lanham Act states. ${ }^{26}$ Ages to the left of the vertical line represent the comparison cohorts, while those to the right represent the treated cohorts. The unconditional DiD effect is given by the difference in adult outcomes for treated individuals born in low- and high-spending states, relative to the birth-state difference for those in the comparison cohorts. This analysis is performed separately for the 1970 (Figure 1), 1980 (Figure 2), and 1990 (Figure 3) Censuses.

All three figures reveal a strong similarity in the outcome trends for comparison cohorts born in low- and high-spending states, providing additional evidence in support of the common trends assumption. In addition, the difference in means between those in high- and low-spending states is quite small (1970 Census: -0.034 SDs; 1980 Census: 0.011 SDs; 1990 Census: 0.019 SDs). However, the gap widens noticeably for the treated cohorts, with those born in high-spending states scoring consistently higher on the outcome index than their counterparts from low-spending states. These relative changes imply an unconditional DiD estimate of approximately $0.10 S D$ s in the 1970 Census, 0.04 SDs in the 1980 Census, and 0.10 SDs in the 1990 Census. Such results provide initial evidence

\footnotetext{
${ }^{26}$ Average Lanham Act spending in the bottom decile is approximately $\$ 8$ per child ages 0 to 12 ; spending in the top decile is $\$ 140$ per child. States in the bottom decile of spending include Idaho, New Mexico, North Dakota, Pennsylvania, and West Virginia. States in the top decile of spending include Arizona, California, Florida, Oregon, and Washington.
} 
that the Lanham Act had positive long-run effects, with the benefits persisting throughout adulthood.

Table 8 presents the baseline regression-adjusted $\mathrm{DiD}$ results. The primary difference between the regression results and the data presented in Figures 2 through 4 is that the former exploits the full distribution of Lanham Act spending rather than simply comparing low- and highspending states. Columns (1) through (3) show the DiD estimates based on the 1970, 1980, and 1990 Censuses, respectively, along with the standard errors (in parentheses). The first row displays the unconditional estimates, while the second row adds the full set of controls discussed previously.

The DiD estimates should be interpreted as intent-to-treat (ITT) effects of the Lanham Act. That is, the estimated parameter averages the impact of reform over treated adults who received and did not receive Lanham Act child care. The ITT is an interesting parameter in this context for several reasons. First, it is useful for characterizing the impact of policy reforms that do not serve the full eligible population. That the Lanham Act did not reach full penetration makes the DiD estimates in this analysis more relevant to the current early care and education landscape, in which most programs (e.g., pre-kindergarten, Head Start, and the CCDF) also do not fully serve the eligible population. Second, the ITT captures the reform effect on exposed non-participants in a program (i.e., noncompliers) who nevertheless use similar services in part because of the reform in question. This is relevant for policies like the Lanham Act, which apparently catalyzed a deep cultural shift in the way Americans viewed institutional child care (Anderson, 1981). This shift may have spurred some families that did not receive Lanham Act child care to use other forms of private non-parental arrangements during the war. The DiD estimates additionally capture the long-run implications of utilizing these non-Lanham Act child care arrangements.

The estimates presented in Table 8 continue to show that the Lanham Act had beneficial and persistent long-run effects. Indeed, the DiD coefficients are consistently positive and highly statistically significant, indicating that increases in Lanham Act spending led to better adult outcomes for the treated cohorts, relative to the comparison cohorts. The DiD estimates also reveal fairly steady 
treatment effect sizes that persist throughout adulthood. In addition, a comparison of rows one (the models without controls) and two (the models with controls) shows that the DiD estimates are robust to the inclusion of demographic covariates, the state Armed Services mobilization rate, and state-ofbirth fixed effects. Adding these controls, however, leads to smaller standard errors, suggesting that they are important primarily for increasing efficiency. Therefore, results in the second row, which incorporate the full set of controls, are considered the baseline DiD estimates.

The DiD estimate in the 1970 Census, which includes treated adults in their mid-20s to late30s, implies that a one-dollar increase Lanham Act spending (per child ages 0 to 12) led to a 0.00024 $S D$ improvement in the outcome summary index. The corresponding effect sizes from the 1980 Census (i.e., treated adults in their mid-30s to late-40s) and 1990 Census (i.e., treated adults in their mid-40s to late-50s) are $0.00015 S D$ s and $0.00021 S D$ s, respectively. To put these results into perspective, I use the DiD estimates to simulate the effect of increasing spending from the Lanham Act median ( $\$ 44$ per child ages 0 to 12$)$ to the level of Georgia's Pre-K program $(\$ 2,000$ per fouryear-old). Georgia's program is chosen because its resource ranking is near the middle of the state distribution (NIEER, 2006; 2012) and because it has been subjected to rigorous evaluation (e.g., Cascio \& Schanzenbach, 2013; Fitzpatrick, 2008). Such an increase in Lanham Act spending translates to improvements in the outcome summary index of $0.47 S D$ s, $0.29 S D$ s, and $0.40 S D$ s, respectively, in the 1970, 1980, and 1990 Censuses. Taking the weighted average all of three produces an overall effect size of $0.36 S D$ s. $^{27}$

Is it useful to compare this long-run effect size to those generated by other early childhood programs. Deming (2009) creates a similar index of young adult outcomes in a study of the long-run effects of Head Start. His primary finding is that Head Start participants scored 0.23 SDs higher on the outcome index, relative to their siblings who did not participate. A recent paper by Anderson

\footnotetext{
${ }^{27}$ I weight by the sample size in each Census.
} 
(2008) reanalyzes data from the Perry and Abecedarian interventions, also using a summary index of adult outcomes. The estimated effect sizes for the Perry program are 0.35 SDs for females and -0.01 $S D$ s for males, while the corresponding effect sizes for Abecedarian are $0.45 S D$ s and $0.31 S D$ s, respectively. Thus, the effect sizes generated by the Lanham Act are large and comparable in magnitude to several prominent early childhood education interventions.

\section{DiD Estimates for the Individual Adult Outcomes}

Table 9 presents results from (2) that replace the outcome summary index with the nine individual outcomes. Columns (1) through (3) show the DiD estimates from the 1970, 1980, and 1990 Censuses, respectively, along with the standard errors (in parentheses). Not surprisingly, the results consistently point to improvements in adult well-being, particularly within the educational attainment and employment domains. It is also noteworthy that most of these well-being gaps remain relatively fixed over time. Looking at the results from the 1990 Census, I find that a $\$ 100$ increase in Lanham Act spending decreased the high school dropout rate by 1.8 percentage points and increased the college completion rate by 1.9 percentage points. This spending increase is also associated with a 0.7 percentage point increase in the fraction currently employed, as well as a 0.3 percentage point increase in the fraction working full-time (conditional on working). The Lanham Act generated a 1.8 percent increase in annual earnings, and it lowered the proportion of adults receiving public assistance, although the DiD estimate for public assistance is not precisely estimated.

The DiD estimates for the family formation outcomes follow an interesting pattern. The Lanham Act is associated with reductions in the marriage rate and increases in single parenthood in the 1970 Census, when treated individuals were ages 24 to 39. However, increases in marriage (of 0.2 percentage points) and reductions in single parenthood (of 0.2 percentage points) are found in the 1990 Census, when treated individuals were ages 44 to 59 . One explanation for this pattern is that treated cohorts may have delayed marriage in order to pursue educational and labor market opportunities throughout early-adulthood. Once formal education was completed by these 
individuals, marriage rates began to climb steadily throughout middle- to late-adulthood relative to those in the comparison group.

\section{Robustness Checks}

Tables 10 and 11 report results from a series of robustness checks. It should be noted that all of the models discussed here are conducted on the outcome summary index and the (nine) individual outcomes. However, to conserve space, only the DiD results for the former are presented. Results for the individual outcomes can be provided upon request.

The first row in Table 10 generates an alternative set of standard errors. Recall that the baseline analyses adjust the standard errors for within-state clustering. This is done to account for the fact that the policy variation (i.e., Lanham Act spending) occurs at the state-level. Nevertheless, the model is identified through an interaction between an indicator for treatment group status, treated, and Lanham Act spending, lanham. Therefore, it may be appropriate to cluster the standard errors according to group-state-of-birth cells. Row (1) presents the DiD estimates and standard errors from such a model. The standard errors are virtually identical to those in the baseline model. In results not reported here, I additionally cluster on year- and state-of-birth cells. Standard errors from these models are also similar to the baseline standard errors.

Individuals in the comparison cohorts are on the leading edge of the post-WWII "baby boom." It has been well-established by Welch (1979) and others (e.g., Freeman, 1979) that the flood of baby boomers into the labor market lowered their earnings relative to other workers. Cohort size is therefore a potentially important alternative explanation for the long-run success of those in the treated cohorts, who were born during the war, relative to those in the comparison cohorts, who were born immediately after the war. Row (2) explores the implications of cohort size by adding to the DiD model a control for the log population in state-of-residence, gender, and age cells. Specifically, I obtained 1980 and 1990 single-year-of-age population counts by gender from the Census Bureau's Population Estimates archive, which were merged to individuals in the IPUMS analysis datasets 
based on state-of-residence, gender, and age. This variable is interacted with treated in the regressions. The DiD estimates are robust to this control. In results not reported here, I test an alternative cohort variable that scales the population counts by the total male or female population in a given state. The DiD estimates are robust to this parameterization as well. Unfortunately, singleyear-of-age population counts are not available in the 1970 Census, which explains why the corresponding estimate is absent from Table 10.

As previously discussed, the Lanham Act funded a variety of public works projects, including the construction of schools and recreation facilities, in addition to funding the child care program. Insofar as these other Lanham Act projects are correlated with the child care component and associated with long-run outcomes, it is important to account for them in the DiD model. Therefore, row (3) in Table 10 adds separate controls for state-level Lanham Act expenditures on schools and recreation, both of which are interacted with treated. These variables are divided by the population of children ages 0 to 12 and expressed in constant 2012 dollars. It is important to note that the expenditure data for these categories is less complete than that for the child program; only data for FY1945 is available. ${ }^{28}$ The DiD estimates for child care are robust to including these additional spending controls, and, if anything, the estimates imply slightly larger effects than the baseline results. Coefficients on the spending controls are frequently statistically insignificant.

Recall that a key assumption in the DiD framework is that the adult outcomes for individuals born in high- and low-spending states would have trended differently in the absence of the Lanham Act. Although the analysis of comparison cohort trends revealed similar time paths in the outcomes across the distribution of Lanham Act spending, I conduct two specification tests to ensure the common trends assumption is satisfied. First, I include several pre-reform state characteristics, drawn from the 1940 Census, that may be correlated with Lanham Act spending. These variables include

\footnotetext{
${ }^{28}$ Average per-child expenditures on schools was \$103 and that on recreation facilities was \$9 in FY1945.
} 
the female employment rate, average female educational attainment (in years), the fraction black, and the fraction of individuals residing on farms. Each variable in interacted with treated to allow for differential effects across the treated and comparison cohorts. As shown in row (4) of Table 10, the DiD estimates are robust to these state-level pre-reform controls. In results not reported here, I experiment with other state characteristics, including the fraction of married women, the fraction of individuals residing in metropolitan areas, and the fraction of individuals born in the U.S. None of the DiD estimates are sensitive to these controls.

Second, I implement a placebo reform that "turns on" the Lanham Act for some cohorts in the comparison group. If the adult outcomes follow a similar time path in low- and high-spending states, then the estimated effect of the placebo reform should be statistically insignificant. I conduct the placebo test by estimating the following regression:

(4) $Y_{\text {its }}=\alpha_{\text {its }}+\beta_{1}$ treated $_{\mathrm{t}}+\beta_{2}$ lanham $_{\mathrm{s}}+\beta_{3}\left(\right.$ treated $_{\mathrm{t}} \times$ lanham $\left._{\mathrm{s}}\right)+\beta_{4}$ placebo $_{\mathrm{t}}+$

$$
\beta_{5}\left(\text { placebo }_{\mathrm{t}} \times \operatorname{lanham}_{\mathrm{s}}\right)+\mathbf{Z}^{\prime} \psi+\gamma m o b_{\mathrm{s}}+v_{\mathrm{s}}+\mu_{\text {ist }},
$$

where $Y$, treated, and lanham are defined in the same manner as in (2). The variable placebo is a binary indicator that equals unity for individuals born in 1949 and 1950. These birth-years correspond to ages 21 and 20 in the 1970 Census, ages 31 and 30 in the 1980 Census, and ages 41 and 40 in the 1990 Census. Such individuals were incorporated in the comparison group in the main DiD analysis. However, in (4) they provide the basis for the falsification test, in which placebo is interacted with lanham and the coefficient on the interaction, $\beta_{5}$, provides an estimate of the differential response to increased Lanham Act spending between cohorts born in 1949 or 1950 and the cohort born in 1951 (i.e., 19-year-olds in 1970, 29-year-olds in 1980, and 39-year-olds in 1990). Thus, individuals born in 1951 comprise the comparison group in the placebo analysis. The primary DiD coefficient, $\beta_{3}$, should be interpreted as a modified DiD effect, in that the treated cohorts are compared to a subset of full comparison group. As shown in Table 11, the placebo estimates are substantially smaller than the corresponding $\mathrm{DiD}$ estimates, and they are never statistically 
significant. The DiD estimates, on the other hand, are similar in magnitude to the baseline estimates

in Table 8. That Lanham Act spending influences those in the treated cohorts, while having no effect on individuals in the comparison group, provides additional evidence in support of the common trends assumption.

Analyses in the next two rows in Table 10 [rows (5) and (6)] adjust the sample in ways that alter the measure of Lanham Act spending. The DiD estimates in row (5) come from a model that explicitly compares outcomes for individuals born in low- and high-spending states. In particular, I create a binary indicator that equals unity if an individual was born in a state in the top quartile of the Lanham Act spending distribution, and zero if an individual was born in a state in the bottom quartile of the distribution. I then interact this variable with treated, so that the coefficient on the interaction captures the DiD effect of having been born in high- versus low-spending states across treated versus comparison cohorts. The results indicate that treated individuals in high-spending states score 0.03 SDs to $0.05 S D$ s higher on the outcomes summary index. Row (6) tests the sensitivity of the DiD estimates to excluding individuals born in California, a state that captured a significant fraction of all Lanham Act spending and that reportedly maintained a number of child care centers after the program was dismantled (Fousekis, 2011). Fortunately, the DiD estimate at each Census date remains highly statistically significant after dropping California births, although the magnitude of the estimates decrease somewhat.

The DiD estimates in the next two rows [rows (7) and (8)] come from models that make sample restrictions based on the number of years age-eligible children were potentially exposed to the Lanham Act. Recall that the child care program operated from mid-1943 to mid-1946; therefore, adults born in 1931 (who were 12-years-old in 1943) or 1946 were exposed to the program for less than one full year. It is debatable whether such individuals should be included in the treated group, and as such it is useful to restrict the sample to adults who were exposed to the Lanham Act for at least one full year. As expected, dropping these adults from the analysis, as shown in row (7), has 
little effect on the DiD estimates. The estimates in row (8) take this analysis a step further, restricting the sample to adults who were exposed to the Lanham Act during the full period of its implementation. Doing so also leaves the DiD estimates unchanged. ${ }^{29}$

To this point, the analysis has focused primarily on educational attainment and labor market behavior as the key markers of adult well-being. Another important outcome domain, however, is health. Indeed, several studies show that early childhood education interventions can have long-run health implications. For example, recent work on the Head Start program finds that participants reveal better long-run health as it relates to mortality and self-reported overall health status (Deming, 2009; Ludwig \& Miller, 2007). In addition, work by Reynolds et al. (2011) shows that participants in the Chicago Child-Parent Centers are more likely to have health insurance and less likely to have depression symptoms. To examine the health effects of the Lanham Act, I use an IPUMS Census item capturing the presence of physical or mental conditions that limit or prevent work. Such conditions are measured with a binary indicator, which is regressed on the full DiD model. As shown in row (9) of Table 10, increases in Lanham Act spending reduced the incidence of work-limiting or -preventing disabilities for treated cohorts. The DiD estimate in the 1990 Census implies that a $\$ 100$ increase in Lanham Act spending decreased the work disability rate by 0.5 percentage points (treated mean: 11.9 percent). As with the education and labor market outcomes, the health benefits appear in early-adulthood and persist throughout the prime working years.

\section{Distributional Effects of the Lanham Act}

A central issue in the debate over the design of early care and education systems is whether a given program should be targeted at specific sub-groups or universally accessible. Implicit in this

\footnotetext{
${ }^{29}$ The timing of the Census, in combination with individuals' date-of-birth, leads to a situation in which a relatively small number of those born in 1946 are in the treated group (in addition to the comparison group, which is the proper placement). I conduct a robustness check that drops those born in 1946 from the analysis of the 1970, 1980, and 1990 Census. I conduct an additional robustness check that drops, by age, those in the last year of the comparison group (age 23, 33, and 43 in the 1970, 1980, and 1990 Census, respectively) and those in the first year of the treated group (age 24, 34, and 44). Results from these specifications are very similar to the baseline estimates.
} 
discussion is the question of the degree to which the effects of early childhood programs are experienced equally by diverse groups of children. To this point, the analysis has estimated DiD ITT effects that are averaged over adults from low- and high-socioeconomic strata and with low- and high-ability endowments. Such average effects are likely to mask substantial heterogeneity if children from different family backgrounds respond differently to early childhood experiences. Indeed, previous work finds that economically disadvantaged children — as defined by family income or parental cognitive ability - generally capture moderate to large benefits from exposure to early childhood programs, while outcomes for their more advantaged peers are either not affected or even adversely affected. For example, a recent study of the Oklahoma and Georgia universal prekindergarten programs finds positive eighth grade test score effects for low-income children and negative (although imprecisely estimated) effects for their high-income counterparts (Cascio \& Schanzenbach, 2013). These patterns are echoed in Deming's (2009) analysis of Head Start and Havnes and Mogstad's (2011a) analysis of Norway's universal child care system. Thus, it is important for the current study to explore heterogeneity in the long-run impact of the Lanham Act.

This task is made somewhat difficult using the Census because data on (adult) respondents' early home environment or parental characteristics are not collected. The approach I take here is to examine whether the Lanham Act influenced the adult outcome distribution for treated relative to comparison cohorts. In particular, I rely on quantile regression methods developed by Firpo et al. (2009) to assess whether, and to what extent, the child care program differentially influenced adult earnings at different points in the distribution. Consistent with the previous DiD analyses, I continue to trace the full lifecycle impact of the Lanham Act by estimating separate sets of quantile treatment effects (QTE) using the 1970, 1980, and 1990 Censuses.

The method proposed by Firpo et al. (2009) provides estimates of the effect of changes in a given right-hand-side variable on the unconditional quantiles of the left-hand-side variable. "Unconditional" in this context simply means the integration of the conditional outcome distribution, 
given a set of explanatory variables, over the distribution of those explanatory variables. The method consists of estimating a regression of the recentered influence function (RIF) — which characterizes the influence of each observation in the data on some distributional statistic — of the outcome variable on one or more explanatory variables. For a given quantile, the $\operatorname{RIF}, \operatorname{RIF}\left(Y, q_{\tau}\right)$, reflects $(\tau-\mathrm{I}\{Y \leq$ $\left.\left.q_{\tau}\right\}\right) / f_{\mathrm{Y}}\left(q_{\tau}\right)$, where $\mathrm{I}\{\cdot\}$ in an indicator function, $f_{\mathrm{Y}}(\cdot)$ is the density of the unconditional distribution of the outcome variable, and $q_{\tau}$ is the population in the $\tau^{\text {th }}$ quantile of the outcome distribution (Firpo et al., 2009). Because of $I\{\cdot\}$, the RIF is a binary variable that equals $\left[-(1-\tau) / f_{\mathrm{Y}}\left(q_{\tau}\right)\right]$ when the observed value of the outcome is below the $\tau^{\text {th }}$ quantile, and it equals $\left[\tau / f_{\mathrm{Y}}\left(q_{\tau}\right)\right]$ when the value is above the $\tau^{\text {th }}$ quantile. The conditional expectation of the outcome is specified as $E\left[\operatorname{RIF}\left(Y ; q_{\tau}\right) \mid X\right]$, which is called the unconditional quantile regression. The conditional expectation at each quantile, $\tau$, referred to as the DiD QTE, is straightforwardly generated using an OLS estimator.

As discussed in Havnes and Mogstad (2012), the DiD QTE requires a slightly different identification assumption from that of the standard DiD model. This stems from the fact that the counterfactual in the DiD QTE is the change among comparison cohorts in the distribution of earnings across those born in low- and high-spending states. Therefore, identification of the various QTE parameters assumes that the change in population shares, $q_{\tau}$, between treated and comparison cohorts at each quantile of earnings would be the same in low- and high-spending states in the absence of the Lanham Act. The reported DiD QTE estimates can be interpreted as the difference in the distribution of earnings at a given quantile for treated individuals born in low- and high-spending states, relative to the birth-state difference for those in the comparison cohorts.

Figures 5 through 7 present the DiD QTE results for the 1970 through 1990 Censuses, respectively. The outcome variable in these analyses is restricted to the log of annual earnings (in the previous year). Each dot depicts a QTE estimate on treated $\times$ lanham at the $\tau^{\text {th }}$ quantile, with the circles indicating that the estimate is statistically significant at the 10 percent level or better. Dots that 
are not encircled are not statistically significant. The standard errors in these regressions are bootstrapped with 500 replications.

Generally speaking, the figures reveal substantial heterogeneity in the impact of the Lanham Act. The largest positive effects are consistently found at the bottom of the earnings distribution, with the QTEs at each Census date peaking at some point in the lowest quartile of earnings. Indeed, the effects peak at the $25^{\text {th }}, 20^{\text {th }}$, and $5^{\text {th }}$ percentiles in the 1970,1980 , and 1990 Census samples, respectively. The QTEs then drop precipitously before flattening out throughout the remainder of the distribution. As shown in the figures, the effects hover just above-or even slightly below—zero starting at the $50^{\text {th }}$ percentile of earnings, if not sooner in the distribution, as is the case in the 1990 Census. Together, the pattern of results suggests that universal child care offered through the Lanham Act compressed the adult earnings distribution, relative to the counterfactual distribution, by increasing the earnings of the lowest-earners substantially more than their higher-earning counterparts.

There are a few other noteworthy observations about the DiD QTE estimates in Figures 5 through 7. First, it appears that most of the earnings compression occured in the 1970 Census, when treated adults are in the early stages of their prime working years (i.e., ages 24 to 39). This can be seen by the larger earnings QTEs in the bottom quartile of the 1970 distribution, relative to the QTEs in the same part of the 1980 and 1990 distributions. Greater compression is also evidenced by the slower flattening out of the QTEs in the 1970 Census. These earnings effects do not flatten out until approximately the $50^{\text {th }}$ percentile; on the other hand, the QTEs in the 1990 Census are fairly steady beginning in the $20^{\text {th }}$ percentile. Second, the QTE estimates for 1970 imply that the Lanham Act had negative effects on adult earnings at the top end of the distribution (i.e., starting at the $60^{\text {th }}$ percentile). Such results are consistent with Havenes and Mogstad's (2012) QTE estimates for the Norwegian universal child care system, and they conform with recent U.S.-based studies of pre- 
kindergarten programs (Cascio \& Schanzenbach, 2013) and non-parental child care arrangements (Herbst, 2013), which uncover negative test score effects on children from more advantaged families.

\section{Conclusion}

With maternal employment rates still on the rise in many Western industrialized nations, there is mounting political pressure to enact some form of universal child care or preschool education. Advocates for these programs point to results from a number of studies showing that such interventions may improve the cognitive and non-cognitive well-being of children. Missing from the debate, however, is credible evidence on the long-run impact of universal early childhood programs. Indeed, the existing body of work is restricted to evaluations of short- to medium-run outcomes (as with pre-kindergarten programs), highly targeted early interventions (as with Head Start or Perry Preschool), or elements of both (as with the U.S. child care subsidy system). Such research may do little to illuminate the ways in which scaled-up, broadly accessible programs, such as President Obama's Preschool for All plan, may influence the long-run outcomes of participant children. The goal of this paper is to provide the first comprehensive analysis of a universal child care programfunded through the Lanham Act of 1940-in the U.S. context.

Several noteworthy results stem from this analysis. First, I find that the Lanham Act produced sizeable increases in maternal employment that were detectable approximately five years after the program was dismantled. It remains an open question whether these employment effects are truly long-run in nature, but as it stands the results are unique in at least two respects. First, studies of education-based early childhood programs (e.g., pre-kindergarten) generally detect little or no shortto medium-run maternal employment response, except within small—usually disadvantaged—subpopulations. The Lanham Act, in contrast, generated approximately equal-sized increases in employment across the young and old, married and unmarried, and low- and high-skilled. Second, although an array of child care programs (from Quebec's universal system to the U.S.'s targeted $\mathrm{CCDF}$ ) yields short-run employment increases, there is little evidence that contemporary child care 
systems are capable of sustaining labor supply in the medium- to long-run. That the Lanham Act continued to increase maternal employment several years after reform should be interpreted cautiously, however, as the program was implemented during a unique period in which rapidly changing views about women's work likely aided in sustaining the longer-run employment effects.

The second noteworthy result is that the Lanham Act had sizeable positive effects on a large number of long-run outcomes related to educational attainment, family formation, and labor market participation. Furthermore, the effects persisted throughout adulthood. Such results accord with Havnes and Mogstad's (2011a) evaluation of Norway's universal child care system, and they are consistent with a growing body of U.S. evidence on targeted, education-based programs, including Head Start. Again, however, there are a few distinguishing features of the Lanham Act's positive impacts. An important pattern established by previous work is that early childhood programs generating large maternal employment effects tend to have negative short-run effects on child development. This is the case with Quebec's universal child care program (Baker et al., 2008) and the U.S. CCDF (Herbst, 2010; Herbst \& Tekin, 2010; 2012). Conversely, programs that produce little or no employment response tend to have positive developmental and school-performance effects in the short-run as well as produce favorable long-run labor market outcomes. This is seen in the Norwegian child care system (Havnes \& Mogstad, 2011a; b), for example, and in studies of U.S. prekindergarten programs (e.g., Cascio \& Schanzenbach, 2013). Such patterns have led some to conclude that early childhood programs face inherent trade-offs between the goals of increased parental employment and enhancing short- and long-run child outcomes. In contrast, the Lanham Act appears to have achieved both policy goals, suggesting that it may illuminate the debate over the design of contemporary early care and education systems.

Results in this paper also shed light on the public debate over the appropriateness of universally-accessible or targeted early childhood programs. The U.S. has traditionally targeted early care and education interventions at economically disadvantaged children, with CCDF-funded child 
care subsidies and Head Start being notable examples. However, President Obama's call for Preschool for All represents a shift toward making state pre-kindergarten programs more broadlyeven universally - accessible. Estimates from the DiD QTE models reveal two results that may be relevant to this debate. First, at least with respect to adult earnings, the Lanham Act had substantially different effects on low- versus high-earning adults. Second, most of the benefits of universal child care accrued to adults at the low end of the earnings distribution. Indeed, the earnings effects for high-earning adults either hovered just above zero or in some instances actually dipped below zero, implying negative effects. Such patterns raise the question of whether universal accessibility is the most cost-effective way of structuring early childhood programs. 


\section{References}

Acemoglu, D., \& Lyle, D. (2004). Women, war, and wages: The effect of female labor supply on the wage structure at midcentury. Journal of Political Economy, 112(3), 497-551.

Anderson, K. (1981). Wartime women: Sex roles, family relations, and the status of women during World War II (p. 3146). Westport, CT: Greenwood Press.

Anderson, P., \& Levine, P. (2000). Child care and mothers' employment decisions. In R.M. Blank \& D.Card (Eds.), Finding jobs: Work and welfare reform. New York, NY: Russell Sage Foundation.

Anderson, M. L. (2008). Multiple inference and gender differences in the effects of early intervention: A reevaluation of the Abecedarian, Perry Preschool, and Early Training Projects. Journal of the American statistical Association, 103(484), 1481-1495.

Baker, M., Gruber, J., \& Milligan, K. (2008). Universal childcare, maternal labor supply, and family well-being. Journal of Political Economy, 116(4), 709-745.

Barnett, W. S., Jung, K., Youn, M., \& Frede, E. (2013). Abbott preschool program longitudinal effects study: Fifth grade follow-up. NIEER Working Paper. Rutgers University: National Institute for Early Education Research.

Black, S., Devereux, P., Loken, K., \& Salvanes, K. (2012). Care or cash? The effect of child care subsidies on student performance. NBER Working paper No. 18086. Cambridge, MA: National Bureau of Economic Research.

Blau, D. M., \& Robins, P. K. (1991). Child care demand and labor supply of young mothers over time. Demography, 28(3), 333-351.

Blau, D., \& Tekin, E. (2007). The determinants and consequences of child care subsidies for single mothers in the USA. Journal of Population Economics, 20(4), 719-741.

Cascio, E. U. (2009). Maternal labor supply and the introduction of kindergartens into American public schools. Journal of Human Resources, 44(1), 140-170.

Cascio, E.U., \& Schanzenbach, D.W. (2013). The Impacts of Expanding Access to High-Quality Preschool Education. Conference draft for the 2013 Brookings Panel on Economic Activity. Washington, DC: Brookings Institution.

Cohen, S. S. (2001). Championing Child Care. New York, NY: Columbia University Press.

Connelly, R., \& Kimmel, J. (2003). The effect of child care costs on the employment and welfare recipiency of single mothers. Southern Economic Journal, 69, 498-519.

Datta Gupta, N., \& Simonsen, M. (2010). Non-cognitive child outcomes and universal high quality child care. Journal of Public Economics, 94(1), 30-43.

Deming, D. (2009). Early childhood intervention and life-cycle skill development: Evidence from Head Start. American Economic Journal: Applied Economics, 1(3), 111-134. 
Dratch, H. (1974). The politics of child care in the 1940s. Science \& Society, 38(2), 167-204.

Gelbach, J. B. (2002). Public schooling for young children and maternal labor supply. American Economic Review, 92(1), 307-322.

Goldin, C. D. (1991). The role of World War II in the rise of women's employment. American Economic Review, 81(4), 741-56.

Goldin, C., \& Olivetti, C. (2013). Shocking labor supply: A reassessment of the role of World War II on women's labor supply. American Economic Review, 103(3), 257-62.

Gormley, W. T., \& Gayer, T. (2005). Promoting school readiness in Oklahoma: An evaluation of Tulsa's pre-k program. Journal of Human Resources, 40(3), 533-558.

Federal Works Agency. (various years). Annual Report of the Federal Works Agency. Washington, DC: Superintendent of Documents, Government Printing Office.

Firpo, S., Fortin, N., \& Lemieux, T. (2009). Unconditional quantile regressions. Econometrica, 77, 953-973.

Fitzpatrick, M. D. (2008). Starting school at four: The effect of universal pre-kindergarten on children's academic achievement. The B.E. Journal of Economic Analysis and Policy, 8(1) Advances, Article 46.

Fitzpatrick, M. D. (2010). Preschoolers enrolled and mothers at work? The effects of universal prekindergarten. Journal of Labor Economics, 28(1), 51-85.

Fitzpatrick, M. D. (2012). Revising our thinking about the relationship between maternal labor supply and preschool. Journal of Human Resources, 47(3), 583-612.

Fousekis, N. M. (2011). Demanding Child Care: Women's Activism and the Politics of Welfare, 1940-1971. University of Illinois Press.

Freeman, R. (1979). The effect of demographic factors on age-earnings profiles. Journal of Human Resources, 14, 289-318.

Havnes, T. \& Mogstad, M. (2011a). No child left behind: Subsidized child care and children's longrun outcomes. American Economic Journal: Economic Policy, 3, 97-129.

Havnes, T., \& Mogstad, M. (2011b). Money for nothing? Universal child care and maternal employment. Journal of Public Economics, 95(11), 1455-1465.

Havnes, T., \& Mogstad, M. (2012). Is universal child care leveling the playing field? CESifo Working Paper No. 4014.

Herbst, C.M. (2010). The Labor Supply Effects of Child Care Costs and Wages in the Presence of Subsidies and the Earned Income Tax Credit. Review of Economics of the Household, 8(2), 199-230. 
Herbst, C.M. (2013). The impact of non-parental child care on child development: Evidence from the summer participation “dip.” Journal of Public Economics, 105, 86-105.

Herbst, C.M. \& Tekin, E. (2010). The Impact of Child Care Subsidies on Child Well-Being: Evidence from Geographic Variation in the Distance to Social Service Agencies. NBER Working Paper No. 16250. Cambridge, MA: National Bureau of Economic Research.

Herbst, C.M. \& Tekin, E. (2012). The Geographic Accessibility of Child Care Subsidies and Evidence on the Impact of Subsidy Receipt on Childhood Obesity. Journal of Urban Economics, 71(1), 37-52.

Koshuk, R. P. (1947). Developmental records of 500 nursery school children. The Journal of Experimental Education, 16(2), 134-148.

Lefebvre, P., \& Merrigan, P. (2008). Child-care policy and the labor supply of mothers with young children: A natural experiment from Canada. Journal of Labor Economics, 26(3), 519-548.

Ludwig, J., \& Miller, D. L. (2007). Does Head Start improve children's life chances? Evidence from a regression discontinuity design. Quarterly Journal of Economics, 122(1), 159-208.

McCormick, M., Brooks-Gunn, J., Buka, S., Goldman, J., Yu, J., Salganik, M., et al. (2006). Early intervention in low birth weight premature infants: Results at 18 years of age for the Infant Health and Development Program. Pediatrics, 117, 771-779.

NIEER (2006). The State of Preschool 2006. Rutgers University: National Institute for Early Education Research.

NIEER (2012). The State of Preschool 2012. Rutgers University: National Institute for Early Education Research.

Reynolds, A. J., Temple, J. A., White, B. A., Ou, S. R., \& Robertson, D. L. (2011). Age 26 costbenefit analysis of the Child-Parent Center Early Education Program. Child development, 82(1), 379404.

Ribar, D. C. (1992). Child care and the labor supply of married women: Reduced form evidence. Journal of Human Resources, 27(1), 134-165.

Riley, S. E. (1994). Caring for Rosie's children: Federal child care policies in the World War II Era. Polity, 655-675.

Ruggles, S., Alexander, T., Genadek, K., Goeken, R., Schroeder, M., \& Sobek, M. (2010). Integrated Public Use Microdata Series: Version 5.0 [Machine-readable database]. Minneapolis: University of Minnesota.

Stoltzfus, E. (2000). Childcare: The federal role during World War II. United States Congressional Research Service, RS20615. 
Tank, M. (1980). Young children, families, and society in America since the 1820s: The evolution of health, education, and child care programs for preschool children. Doctoral Dissertation. Ann Arbor, MI: University of Michigan.

Tekin, E. (2005). Child care subsidy receipt, employment, and child care choices of single mothers. Economics Letters, 89(1), 1-6.

Tekin, E. (2007a). Childcare subsidies, wages, and employment of single mothers. Journal of Human Resources, 42(2), 453-487.

Tekin, E. (2007b). Single mothers working at night: Standard work and child care subsidies. Economic Inquiry, 45(2), 233-250.

Tuttle Jr, W. M. (1995). Rosie the riveter and her latchkey children: What Americans can learn about child day care from the Second World War. Child Welfare, 74(1), 92-114.

U.S. House of Representatives. (1945). To Amend Section 204, Title II, of the Act to Expedite Provision of Housing. Committee on Public Buildings and Grounds. $79^{\text {th }}$ Congress, $1^{\text {st }}$ session, May 16 and 22, 1945.

U.S. Senate (1943a). Wartime Care and Protection of Children of Employed Mothers. Committee on Education and Labor. $78^{\text {th }}$ Congress, $1^{\text {st }}$ session, June 8, 1943.

U.S. Senate (1943a). Wartime Health and Education. Committee on Education and Labor, Subcommittee on Wartime Health and Education. $78^{\text {th }}$ Congress, December 2, 1943.

Weiland, C., \& Yoshikawa, H. (2013). Impacts of a Prekindergarten Program on Children's Mathematics, Language, Literacy, Executive Function, and Emotional Skills. Child Development, 84(6), 2112-2130.

Welch, F. (1979). Effects of cohort size on earnings: The baby boom babies' bust. Journal of Political Economy, 87, S65-S97.

Youcha, G. (1995). Minding the children: Child care in America from colonial times to the present. New York, NY: Scribner. 
Figure 1: State-Level Lanham Act Child Care Expenditures (per child ages 0-12)

State-Level Lanham Act Child Care Expenditures (per child ages 0-12)

- 1st Quartile

- 2nd Quartile

- 3rd Quartile

- 4th Quartile
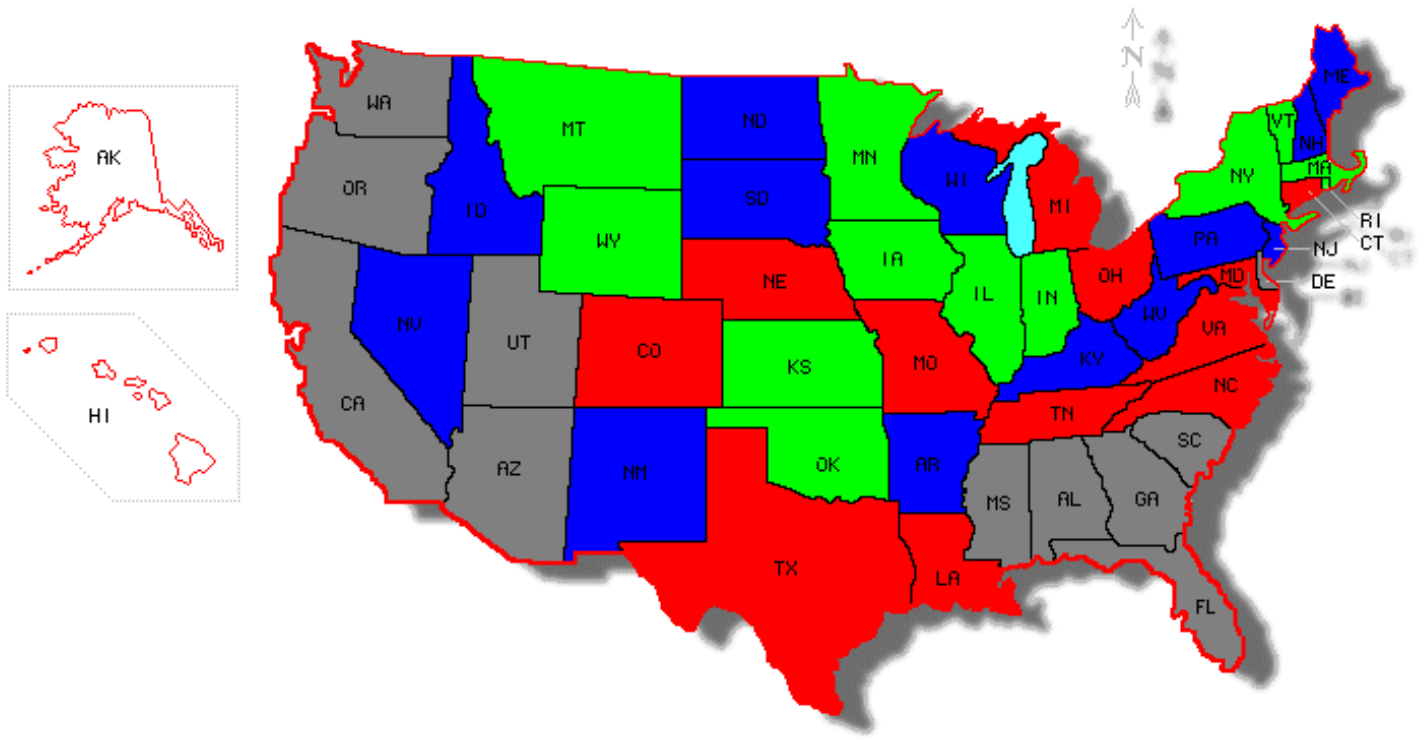
Figure 2: Mean Score on the Outcome Summary Index, by Lanham Act Spending Percentile Source: 1970 U.S. Decennial Census

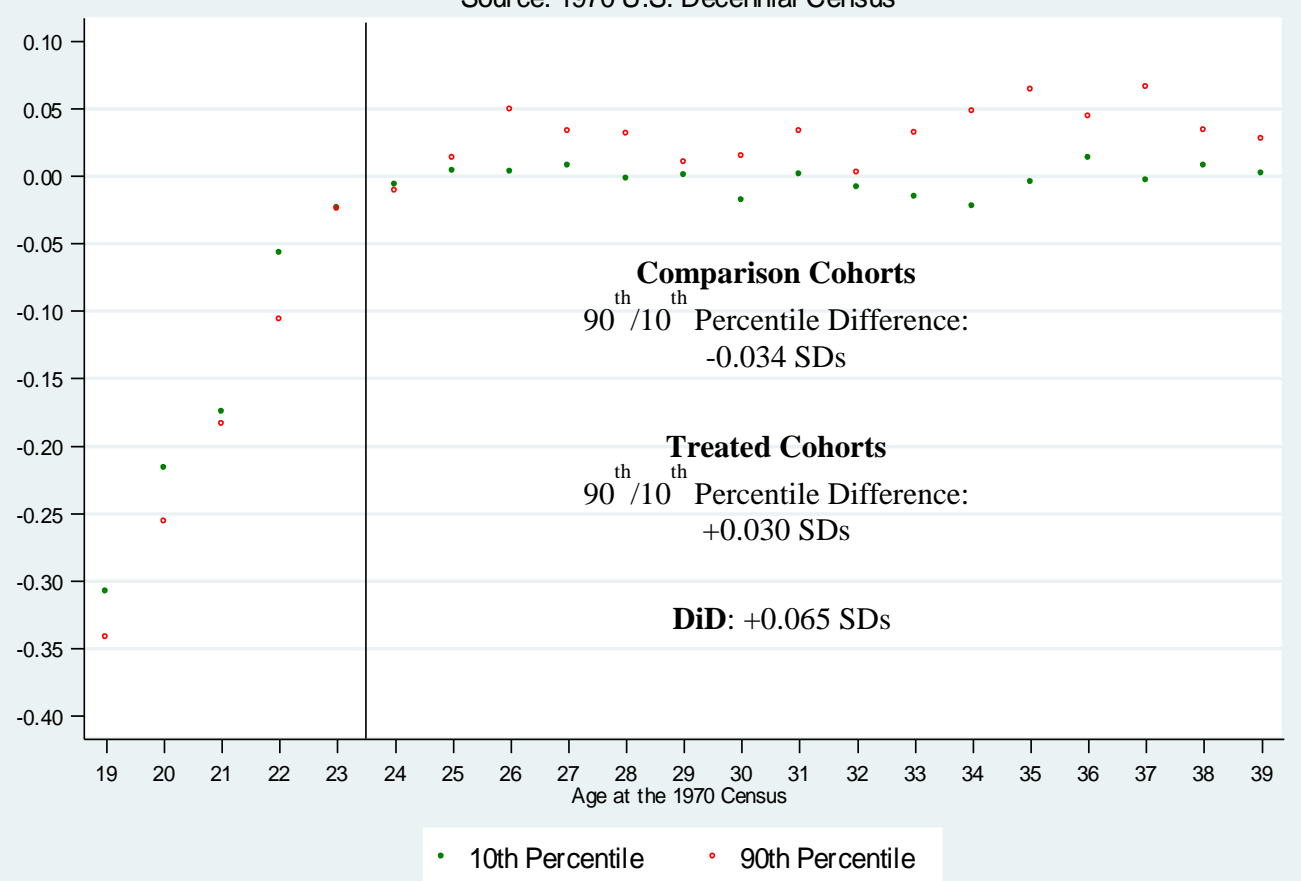

Figure 3: Mean Score on the Outcome Summary Index, by Lanham Act Spending Percentile Source: 1980 U.S. Decennial Census

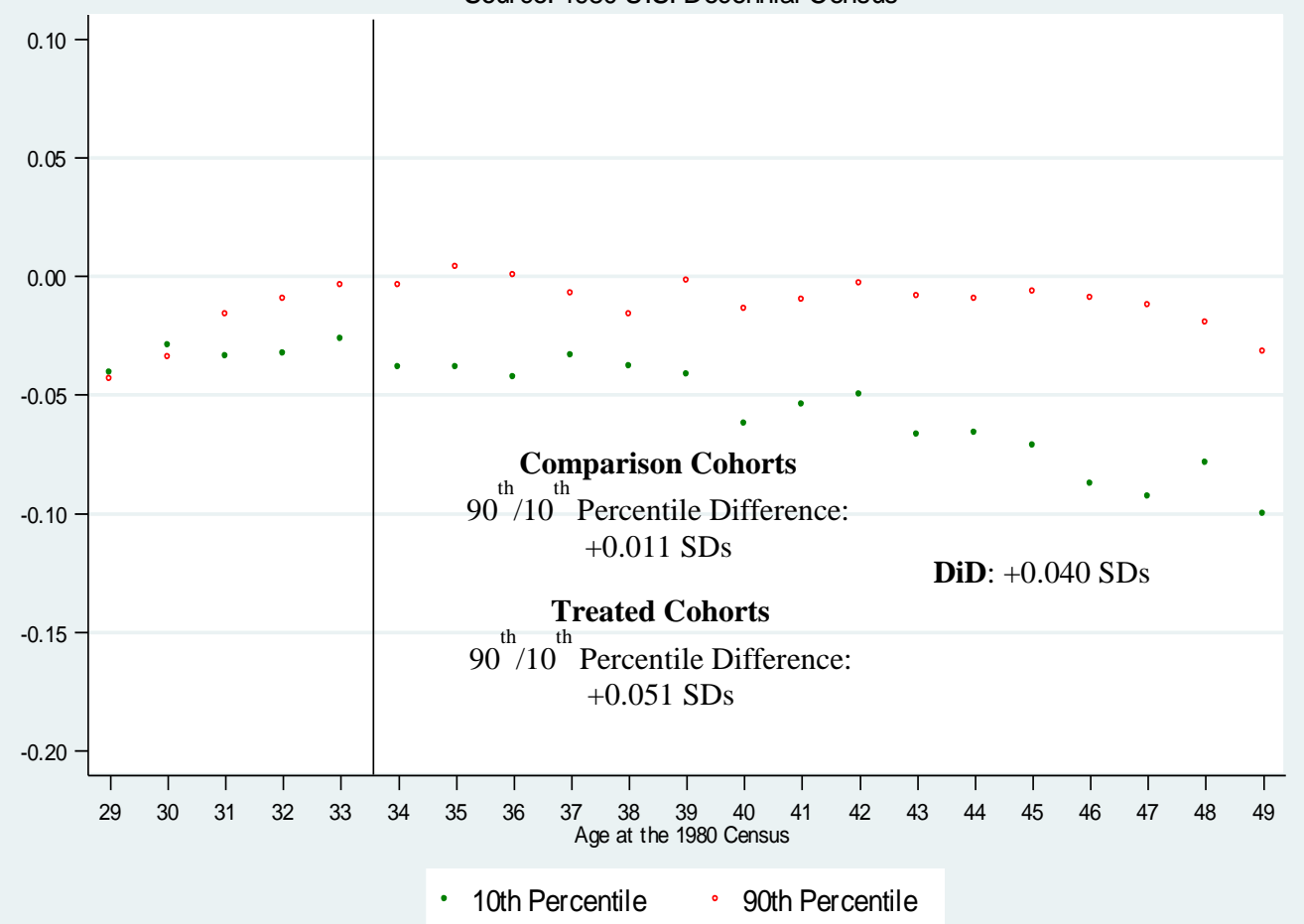


Figure 4: Mean Score on the Outcome Summary Index, by Lanham Act Spending Percentile Source: 1990 U.S. Decennial Census

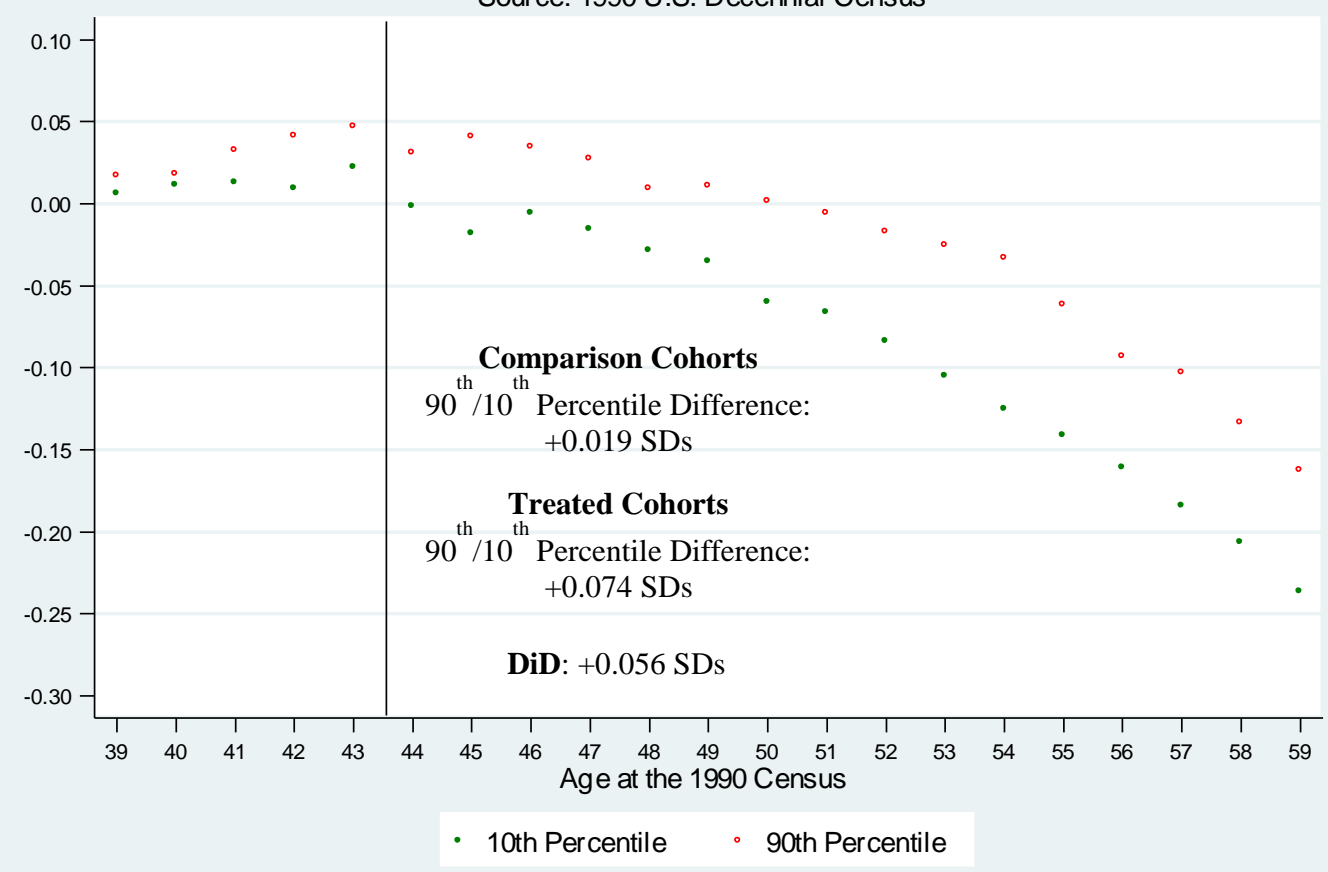



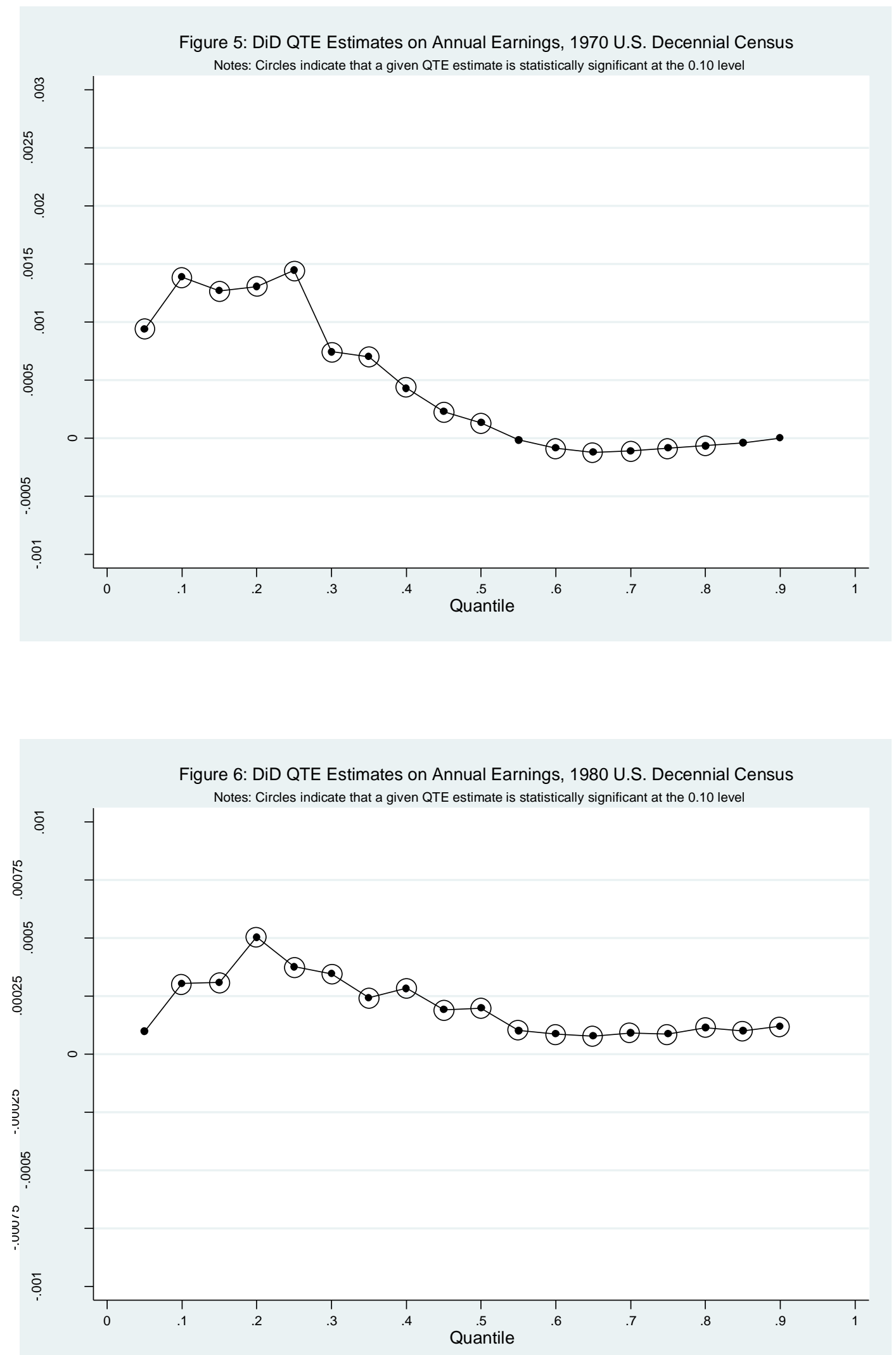


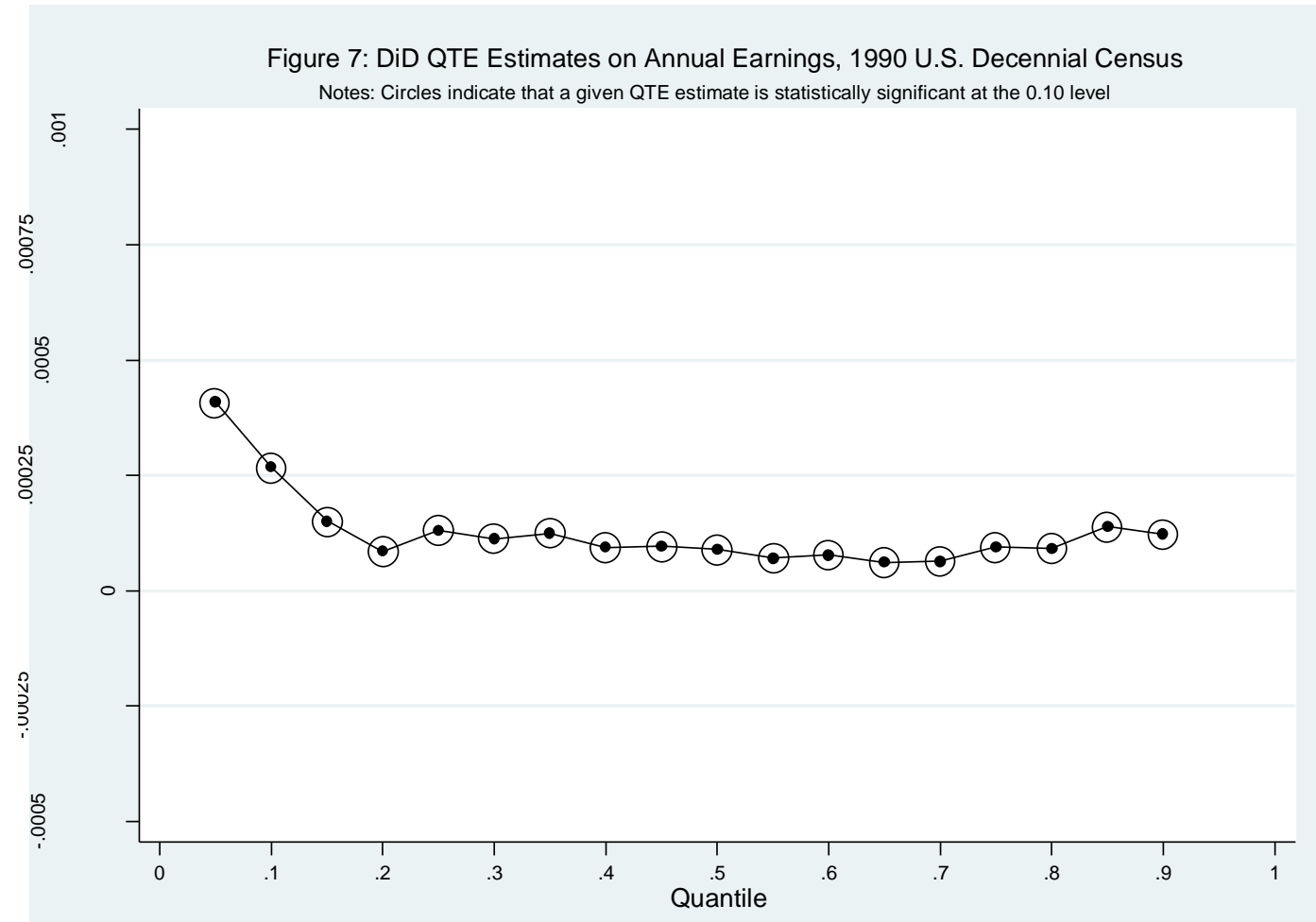


Table 1: State-Level Determinants of Lanham Act Child Care Spending

\begin{tabular}{|c|c|c|c|c|c|c|c|}
\hline Variable & (1) & (2) & (3) & (4) & (5) & (6) & (7) \\
\hline Coastal state $(=1)$ & $\begin{array}{l}45.61 * * \\
(17.62)\end{array}$ & & & $\begin{array}{l}47.26^{* *} \\
(19.15)\end{array}$ & & & $\begin{array}{l}52.97 * * \\
(25.75)\end{array}$ \\
\hline Willkie $(=1)$ & & $\begin{array}{l}-16.11 \\
(27.11)\end{array}$ & & $\begin{array}{c}6.88 \\
(27.71)\end{array}$ & & & \\
\hline Mobilization rate (\%) & & & $\begin{array}{c}-60.02 \\
(287.50)\end{array}$ & $\begin{array}{c}-58.16 \\
(275.10)\end{array}$ & & & \\
\hline Female education (yrs.) & & & & & $\begin{array}{c}33.95 * * \\
(14.29)\end{array}$ & & $\begin{array}{l}40.09 * * * \\
(13.38)\end{array}$ \\
\hline Female employment (\%) & & & & & & $\begin{array}{c}400.93 * \\
(229.62)\end{array}$ & $\begin{array}{l}-1.99 \\
(325.41)\end{array}$ \\
\hline Observations & 48 & 48 & 48 & 48 & 48 & 48 & 48 \\
\hline $\mathrm{R}^{2}$ & 0.127 & 0.008 & 0.001 & 0.130 & 0.109 & 0.063 & 0.277 \\
\hline
\end{tabular}


Table 2: Summary Statistics for Women in the Treated and Comparison Groups

\begin{tabular}{|c|c|c|c|c|}
\hline \multirow[b]{2}{*}{ Variable } & \multicolumn{2}{|c|}{1940 Census: Pre-Reform } & \multicolumn{2}{|c|}{1950 Census: Post-Reform } \\
\hline & $\begin{array}{c}\text { Treated } \\
\text { (1) }\end{array}$ & $\begin{array}{c}\text { Comparison } \\
\text { (2) }\end{array}$ & $\begin{array}{c}\text { Treated } \\
\text { (3) }\end{array}$ & $\begin{array}{c}\text { Comparison } \\
\text { (4) }\end{array}$ \\
\hline \multirow[t]{2}{*}{ Age (years) } & 40.80 & 42.97 & 40.17 & 45.08 \\
\hline & $(8.22)$ & $(11.97)$ & $(7.84)$ & $(11.53)$ \\
\hline \multirow[t]{2}{*}{ Married (\%) } & 0.905 & 0.597 & 0.905 & 0.621 \\
\hline & $(0.293)$ & $(0.491)$ & $(0.293)$ & $(0.485)$ \\
\hline \multirow[t]{2}{*}{ Single, never married (\%) } & 0.003 & 0.280 & 0.002 & 0.236 \\
\hline & $(0.053)$ & $(0.449)$ & $(0.044)$ & $(0.424)$ \\
\hline \multirow[t]{2}{*}{ High school or less (\%) } & 0.906 & 0.853 & 0.868 & 0.832 \\
\hline & $(0.291)$ & $(0.355)$ & $(0.338)$ & $(0.374)$ \\
\hline \multirow[t]{2}{*}{ No own children (\%) } & 0.000 & 0.877 & 0.000 & 0.857 \\
\hline & $(0.000)$ & $(0.329)$ & $(0.000)$ & $(0.350)$ \\
\hline \multirow[t]{2}{*}{ One own child (\%) } & 0.333 & 0.072 & 0.297 & 0.088 \\
\hline & $(0.471)$ & $(0.259)$ & $(0.457)$ & $(0.284)$ \\
\hline \multirow[t]{2}{*}{ Two+ own children $(\%)$} & 0.667 & 0.051 & 0.703 & 0.055 \\
\hline & $(0.471)$ & $(0.220)$ & $(0.457)$ & $(0.227)$ \\
\hline \multirow[t]{2}{*}{ U.S. born (\%) } & 0.810 & 0.857 & 0.901 & 0.874 \\
\hline & $(0.393)$ & $(0.350)$ & $(0.299)$ & $(0.332)$ \\
\hline \multirow[t]{2}{*}{ Metropolitan residence (\%) } & 0.636 & 0.679 & 0.619 & 0.691 \\
\hline & $(0.481)$ & $(0.467)$ & $(0.486)$ & $(0.462)$ \\
\hline
\end{tabular}

Source: Author's analysis of the 1940 and 1950 U.S. Decennial Census (IPUMS)

Notes: Standard deviations are in parentheses. Treated women are those whose youngest child is ages four to 19 in the 1940 and 1950

Census. Comparison women are those whose youngest child is ages 20 to 24 in the 1940 and 1950 Census and those who are childless. 
Table 3: Summary Statistics for the Employment Outcomes

\begin{tabular}{|c|c|c|c|c|}
\hline \multirow[b]{2}{*}{ Outcome } & \multicolumn{2}{|c|}{1940 Census: Pre-Reform } & \multicolumn{2}{|c|}{1950 Census: Post-Reform } \\
\hline & $\begin{array}{c}\text { Treated } \\
\text { (1) }\end{array}$ & $\begin{array}{c}\text { Comparison } \\
\text { (2) }\end{array}$ & $\begin{array}{c}\text { Treated } \\
\text { (3) }\end{array}$ & $\begin{array}{c}\text { Comparison } \\
\text { (4) }\end{array}$ \\
\hline \multirow[t]{4}{*}{ Employed (\%) } & 0.159 & 0.402 & 0.258 & 0.457 \\
\hline & $(0.365)$ & $(0.490)$ & $(0.438)$ & $(0.498)$ \\
\hline & \multicolumn{2}{|c|}{ Difference: -0.243} & \multicolumn{2}{|c|}{ Difference: -0.199} \\
\hline & \multicolumn{4}{|c|}{ DiD estimate: $0.044^{* * *}(0.004)$} \\
\hline \multirow[t]{3}{*}{ Hours of work (no.) } & $\begin{array}{c}5.61 \\
(14.78)\end{array}$ & $\begin{array}{c}15.80 \\
(21.56)\end{array}$ & $\begin{array}{c}9.54 \\
(17.85)\end{array}$ & $\begin{array}{c}17.82 \\
(21.15)\end{array}$ \\
\hline & Diffe & -10.19 & \multicolumn{2}{|c|}{ Difference: -8.28} \\
\hline & \multicolumn{4}{|c|}{ DiD estimate: $1.915^{* * *}(0.153)$} \\
\hline
\end{tabular}

Source: Author's analysis of the 1940 and 1950 U.S. Decennial Census (IPUMS)

Notes: Standard deviations are in parentheses. Treated women are those whose youngest child is ages four to 19 in the 1940 and 1950 Census. Comparison women are those whose youngest child is ages 20 to 24 in the 1940 and 1950 Census and those who are childless. The means for weekly hours of work are not conditioned on having non-zero hours. The difference-in-differences estimates are generated by the following equation: $Y_{\text {ist }}=\beta_{1}$ treated $_{\text {ist }}+\beta_{2}$ post $_{\mathrm{t}}+\beta_{3}\left(\right.$ treated $_{\text {ist }} \times$ post $\left._{\mathrm{t}}\right)+\mu_{\mathrm{ist} .} * * *, * *$, and * indicate statistical significance at the $0.01,0.05$, and 0.10 levels, respectively.

Table 4: Main DiDiD Employment Results

\begin{tabular}{lcccc}
\hline Variable & $\mathbf{( 1 )}$ & $\mathbf{( 2 )}$ & $\mathbf{( 3 )}$ & $\mathbf{( 4 )}$ \\
\hline treated $_{\text {ist }} \times$ post $_{\mathrm{t}} \times$ lanham $_{\mathrm{s}}$ & $0.0021 * * *$ & $0.0010^{* * *}$ & $0.0893 * * *$ & $0.0428^{* * *}$ \\
& $(0.0007)$ & $(0.0003)$ & $(0.0277)$ & $(0.0127)$ \\
Outcome & & & & \\
Controls & Employed & Employed & Hours of Work & Hours of Work \\
Outcome mean & No & Yes & No & Yes \\
Observations & 0.159 & 0.159 & 5.61 & 5.61 \\
\hline
\end{tabular}

Source: Author's analysis of the 1940 and 1950 U.S. Decennial Census (IPUMS)

Notes: Standard errors (in parentheses) are adjusted for state-level clustering. Columns (1) and (3) do not include controls (with the exception of age fixed effects), while columns (2) and (4) include the full set of demographic controls (as well as the state fixed effects) discussed in the text. The outcome mean refers to the pre-reform employment mean for the treated group. ***, **, and * indicate statistical significance at the $0.01,0.05$, and 0.10 levels, respectively. 
Table 5: Robustness Checks and Sub-Group Analyses

\begin{tabular}{|c|c|c|c|c|}
\hline Variable & $\begin{array}{c}\text { (1a) } \\
\text { DiDiD Coeff }\end{array}$ & $\begin{array}{l}\text { (1b) } \\
\text { SE }\end{array}$ & $\begin{array}{c}\text { (2a) } \\
\text { DiDiD Coeff }\end{array}$ & $\begin{array}{l}(2 \mathrm{~b}) \\
\mathrm{SE}\end{array}$ \\
\hline $\begin{array}{l}\text { Panel A: Robustness Checks } \\
\text { State mobilization rate }\end{array}$ & $0.0010 * * *$ & $(0.0003)$ & $0.0429 * * *$ & $(0.0126)$ \\
\hline Pre-reform state characteristics & $0.0010 * * *$ & $(0.0003)$ & $0.0409 * * *$ & $(0.0113)$ \\
\hline $\begin{array}{l}\text { Panel B: Sub-Group Analyses } \\
\text { Youngest child: ages 0-5 }\end{array}$ & $0.0013 * * *$ & $(0.0004)$ & $0.0539 * * *$ & $(0.0148)$ \\
\hline Youngest child: ages 6-12 & $0.0007 * * *$ & $(0.0002)$ & $0.0320 * * *$ & $(0.0103)$ \\
\hline Women ages $25-44$ & $0.0012 * * *$ & $(0.0004)$ & $0.0524 * * *$ & $(0.0173)$ \\
\hline Women ages 45-64 & $0.0008 * * *$ & $(0.0002)$ & $0.0344 * * *$ & $(0.0073)$ \\
\hline Married & $0.0010^{* * *}$ & $(0.0003)$ & $0.0400 * * *$ & $(0.0124)$ \\
\hline Unmarried & $0.0007 * * *$ & $(0.0002)$ & $0.0463 * * *$ & $(0.0135)$ \\
\hline$<$ High school & $0.0010 * * *$ & $(0.0003)$ & $0.0439 * * *$ & $(0.0126)$ \\
\hline$=>$ High school & $0.0010 * * *$ & $(0.0003)$ & $0.0427 * * *$ & $(0.0119)$ \\
\hline Outcome & \multicolumn{2}{|c|}{ Employed } & \multicolumn{2}{|c|}{ Hours of Work } \\
\hline \multicolumn{5}{|c|}{ 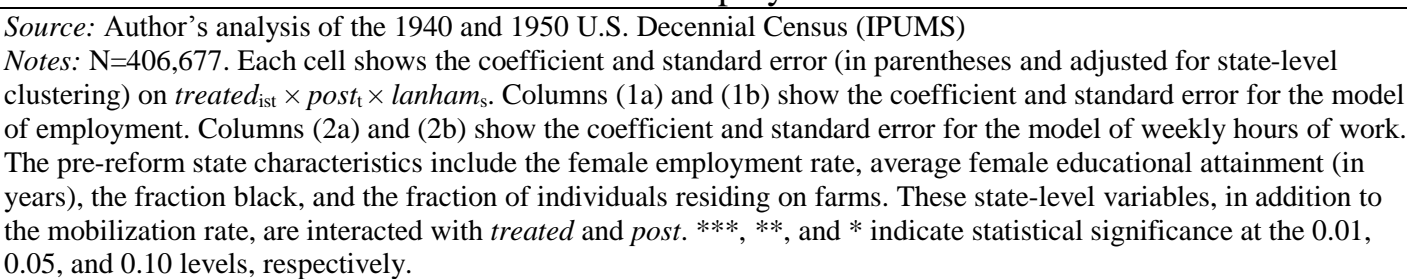 } \\
\hline
\end{tabular}


Table 6: Summary Statistics for the Adult Outcomes in the 1970, 1980, and 1990 Census

\begin{tabular}{lccc}
\hline Variable & $\mathbf{1 9 7 0}$ Census & $\mathbf{1 9 8 0}$ Census & $\mathbf{1 9 9 0}$ Census \\
\hline High school dropout $(\%)$ & $\mathbf{( 1 )}$ & $(\mathbf{2})$ & $(\mathbf{3})$ \\
& 0.235 & 0.174 & 0.135 \\
$\mathrm{BA}+(\%)$ & $(0.424)$ & $(0.379)$ & $(0.342)$ \\
& 0.143 & 0.225 & 0.240 \\
Married $(\%)$ & $(0.350)$ & $(0.418)$ & $(0.427)$ \\
& 0.744 & 0.800 & 0.780 \\
Unmarried parent $(\%)$ & $(0.436)$ & $(0.400)$ & $(0.414)$ \\
& 0.031 & 0.061 & 0.065 \\
Employed $(\%)$ & $(0.175)$ & $(0.239)$ & $(0.247)$ \\
& 0.668 & 0.761 & 0.779 \\
Employed full-time $(\%)$ & $(0.471)$ & $(0.426)$ & $(0.415)$ \\
& 0.824 & 0.850 & 0.850 \\
Employed last year $(\%)$ & $(0.381)$ & $(0.357)$ & $(0.357)$ \\
& 0.776 & 0.819 & 0.834 \\
Earnings last year $(\$ 2012)$ & $(0.417)$ & $(0.385)$ & $(0.373)$ \\
Public assistance $(\%)$ & 36,252 & 47,383 & 53,239 \\
& $(28,591)$ & $(35,910)$ & $(50,185)$ \\
\hline Souce: Aus & 0.016 & 0.023 & 0.021 \\
& $(0.124)$ & $(0.150)$ & $(0.143)$ \\
\hline
\end{tabular}

Source: Author's analysis of the 1970, 1980, and 1990 U.S. Decennial Census (IPUMS)

Notes: Standard deviations are in parentheses. 
Table 7: Trends in the Comparison Cohort's Adult Outcome Index by State-Level Lanham Act Spending Quartile

\begin{tabular}{|c|c|c|c|}
\hline Variable & (1) & (2) & (3) \\
\hline lanhamQ1 $\times$ trend & $\begin{array}{l}-0.0684 * * * \\
(0.0020)\end{array}$ & $\begin{array}{l}-0.0027 * * * \\
(0.0010)\end{array}$ & $\begin{array}{l}-0.0007 \\
(0.0009)\end{array}$ \\
\hline lanham $Q 2 \times$ trend & $\begin{array}{l}-0.0846^{* * *} \\
(0.0015)\end{array}$ & $\begin{array}{l}-0.0027 * * * \\
(0.0007)\end{array}$ & $\begin{array}{l}-0.0027 * * * \\
(0.0007)\end{array}$ \\
\hline lanhamQ3 $\times$ trend & $\begin{array}{l}-0.0752 * * * \\
(0.0015)\end{array}$ & $\begin{array}{l}-0.0043 * * * \\
(0.0007)\end{array}$ & $\begin{array}{l}-0.0031 * * * \\
(0.0007)\end{array}$ \\
\hline lanham $Q 4 \times$ trend & $\begin{array}{l}-0.0781 * * * \\
(0.0019)\end{array}$ & $\begin{array}{l}-0.0084 * * * \\
(0.0009)\end{array}$ & $\begin{array}{l}-0.0041 * * * \\
(0.0009)\end{array}$ \\
\hline Census sample & 1970 & 1980 & 1990 \\
\hline Comparison cohorts' age range & 23 to 19 & 33 to 29 & 43 to 39 \\
\hline Observations & 112,834 & 702,703 & 714,575 \\
\hline
\end{tabular}

Source: Author's analysis of the 1970, 1980, and 1990 U.S. Decennial Census (IPUMS)

Notes: Standard errors are in parentheses. The dependent variable in each model is the adult outcome summary index. Also included are (three) dummy variables indicating the Lanham Act spending quartile for the state in which a given individual was born. $* * *, * *$, and $*$ indicate statistical significance at the $0.01,0.05$, and 0.10 levels, respectively.

Table 8: Baseline DiD Results for the Impact of the Lanham Act on the Adult Outcome Summary Index

\begin{tabular}{lccc}
\hline Model & $\mathbf{( 1 )}$ & $\mathbf{( 2 )}$ & $\mathbf{( 3 )}$ \\
\hline No controls & $0.00024^{* * *}$ & $0.00014^{* * *}$ & $0.00019^{* * *}$ \\
& $(0.00004)$ & $(0.00004)$ & $(0.00005)$ \\
& & & \\
All controls & $0.00024^{* * *}$ & $0.00015^{* * *}$ & $0.00021^{* * * *}$ \\
& $(0.00004)$ & $(0.00002)$ & $(0.00003)$ \\
& & & \\
Census sample & 1970 & 1980 & 1990 \\
Treated cohorts' age range & 24 to 39 & 34 to 49 & 44 to 59 \\
Observations & 405,952 & $2,215,767$ & $2,244,721$ \\
\hline
\end{tabular}

Source: Author's analysis of the 1970, 1980, and 1990 U.S. Decennial Census (IPUMS)

Notes: Displayed in each cell is the coefficient on treated $\times$ lanham and its standard error (in parentheses), which is adjusted for state-level clustering. Results presented in column (1) come from the 1970 Census; those in column (2) are from the 1980 Census; and those in column (3) are from the 1990 Census. The models in the first row do not include controls, while those in the second row include the full set of demographic controls, state-ofbirth fixed effects, and the state-level Armed Services mobilization rate (interacted with treated). ***, **, and * indicate statistical significance at the $0.01,0.05$, and 0.10 levels, respectively. 
Table 9: DiD Results for the Impact of the Lanham Act on the Individual Adult Outcomes

\begin{tabular}{|c|c|c|c|}
\hline Outcome & (1) & (2) & (3) \\
\hline High school dropout & $\begin{array}{c}-0.00019 * * * \\
(0.00003) \\
{[0.189]}\end{array}$ & $\begin{array}{c}-0.00017 * * * \\
(0.00003) \\
{[0.114]}\end{array}$ & $\begin{array}{c}-0.00018 * * * \\
(0.00003) \\
{[0.079]}\end{array}$ \\
\hline $\mathrm{BA}+$ & $\begin{array}{c}0.00020 * * * \\
(0.00004) \\
{[0.077]}\end{array}$ & $\begin{array}{c}0.00021 * * * \\
(0.00002) \\
{[0.272]}\end{array}$ & $\begin{array}{c}0.00019 * * * \\
(0.00003) \\
{[0.294]}\end{array}$ \\
\hline Married & $\begin{array}{c}-0.00018 \\
(0.00012) \\
{[0.492]}\end{array}$ & $\begin{array}{c}6.15 \mathrm{e}-06 \\
(0.00002) \\
{[0.754]}\end{array}$ & $\begin{array}{c}0.00002 * \\
(9.60 \mathrm{e}-06) \\
{[0.765]}\end{array}$ \\
\hline Unmarried parent & $\begin{array}{c}0.00002^{*} \\
(0.00001) \\
{[0.020]}\end{array}$ & $\begin{array}{c}0.00002 \\
(0.00001) \\
{[0.053]}\end{array}$ & $\begin{array}{c}-0.00002 * * * \\
(7.75 \mathrm{e}-06) \\
{[0.078]}\end{array}$ \\
\hline Employed & $\begin{array}{c}0.00016 * * * \\
(0.00003) \\
{[0.641]}\end{array}$ & $\begin{array}{c}0.00001 \\
(0.00002) \\
{[0.758]}\end{array}$ & $\begin{array}{c}0.00007 * * * \\
(0.00002) \\
{[0.836]}\end{array}$ \\
\hline Employed full-time & $\begin{array}{c}0.00031 * * * \\
(0.00007) \\
{[0.759]}\end{array}$ & $\begin{array}{c}0.00005 * * * \\
(0.00002) \\
{[0.849]}\end{array}$ & $\begin{array}{c}0.00003 * * \\
(0.00001) \\
{[0.853]}\end{array}$ \\
\hline Employed last year & $\begin{array}{c}0.00011 * * \\
(0.00005) \\
{[0.828]}\end{array}$ & $\begin{array}{c}-8.81 \mathrm{e}-06 \\
(0.00002) \\
{[0.830]}\end{array}$ & $\begin{array}{c}0.00006 * * * \\
(0.00002) \\
{[0.853]}\end{array}$ \\
\hline $\ln$ (earnings last year) & $\begin{array}{c}0.00060 * * * \\
(0.00018) \\
{[7.706]}\end{array}$ & $\begin{array}{c}0.00021 * * * \\
(0.00003) \\
{[9.149]}\end{array}$ & $\begin{array}{c}0.00018 * * * \\
(0.00005) \\
{[9.869]}\end{array}$ \\
\hline Public assistance & $\begin{array}{c}-7.08 \mathrm{e}-06 \\
(5.70 \mathrm{e}-06) \\
{[0.015]}\end{array}$ & $\begin{array}{c}-0.00001^{*} \\
(7.39 \mathrm{e}-06) \\
{[0.026]}\end{array}$ & $\begin{array}{c}-7.47 \mathrm{e}-06 \\
(5.74 \mathrm{e}-06) \\
{[0.021]}\end{array}$ \\
\hline Census sample & 1970 & 1980 & 1990 \\
\hline \multicolumn{4}{|c|}{$\begin{array}{l}\text { Source: Author's analysis of the } 1970,1980, \text { and } 1990 \text { U.S. Decennial Census (IPUMS) } \\
\text { Notes: Displayed in each cell is the coefficient on treated } \times \text { lanham and its standard error (in } \\
\text { parentheses), which is adjusted for state-level clustering. The figures in brackets are the outcome means } \\
\text { for the comparison cohorts. Results presented in column (1) come from the } 1970 \text { Census; those in column } \\
\text { (2) are from the } 1980 \text { Census; and those in column (3) are from the } 1990 \text { Census. All models include the } \\
\text { full set of demographic controls, state-of-birth fixed effects, and the state-level Armed Services } \\
\text { mobilization rate (interacted with treated). ***, **, and * indicate statistical significance at the } 0.01,0.05 \text {, } \\
\text { and } 0.10 \text { levels, respectively. }\end{array}$} \\
\hline
\end{tabular}


Table 10: Robustness Checks on the Baseline DiD Estimates

\begin{tabular}{|c|c|c|c|}
\hline Model & (1) & (2) & (3) \\
\hline (1) Cluster on group-state cells & $\begin{array}{l}0.00024 * * * \\
(0.00004)\end{array}$ & $\begin{array}{l}0.00015 * * * \\
(0.00002)\end{array}$ & $\begin{array}{l}0.00021 \text { *** } \\
(0.00004)\end{array}$ \\
\hline (2) Control for cohort size & -- & $\begin{array}{l}0.00013 * * * \\
(0.00003)\end{array}$ & $\begin{array}{l}0.00015^{* * * *} \\
(0.00004)\end{array}$ \\
\hline (3) Other Lanham Act categories & $\begin{array}{l}0.00033 * * * \\
(0.00004)\end{array}$ & $\begin{array}{l}0.00024 * * * \\
(0.00003)\end{array}$ & $\begin{array}{l}0.00033 * * * \\
(0.00005)\end{array}$ \\
\hline (4) Pre-reform state characteristics & $\begin{array}{l}0.00013 * * * \\
(0.00004)\end{array}$ & $\begin{array}{l}0.00006^{* *} \\
(0.00002)\end{array}$ & $\begin{array}{l}0.00009 * * * \\
(0.00003)\end{array}$ \\
\hline (5) $75^{\text {th }}$ vs. $25^{\text {th }}$ spending percentile & $\begin{array}{l}0.05310 * * * \\
(0.01278)\end{array}$ & $\begin{array}{l}0.02705^{* *} \\
(0.01025)\end{array}$ & $\begin{array}{l}0.04247 * * * \\
(0.01218)\end{array}$ \\
\hline (6) Omit individuals born in CA & $\begin{array}{l}0.00017 * * * \\
(0.00005)\end{array}$ & $\begin{array}{l}0.00009 * * \\
(0.00005)\end{array}$ & $\begin{array}{l}0.00011^{* *} \\
(0.00005)\end{array}$ \\
\hline (7) Omit $<1$ full year of exposure & $\begin{array}{l}0.00026^{* * *} \\
(0.00004\end{array}$ & $\begin{array}{l}0.00015^{* * *} \\
(0.00002)\end{array}$ & $\begin{array}{l}0.00020 * * * \\
(0.00003)\end{array}$ \\
\hline (8) Those with 4 years of exposure & $\begin{array}{l}0.00025 * * * \\
(0.00004)\end{array}$ & $\begin{array}{l}0.00014 * * * \\
(0.00002)\end{array}$ & $\begin{array}{l}0.00018 * * * \\
(0.00003)\end{array}$ \\
\hline (9) Health outcome: work disability & $\begin{array}{l}-0.00003 * * * \\
(9.24 \mathrm{e}-06)\end{array}$ & $\begin{array}{l}-0.00002 \\
(0.00001)\end{array}$ & $\begin{array}{l}-0.00005^{* *} \\
(0.00002)\end{array}$ \\
\hline Census sample & 1970 & 1980 & 1990 \\
\hline
\end{tabular}

Source: Author's analysis of the 1970, 1980, and 1990 U.S. Decennial Census (IPUMS)

Notes: Displayed in each cell is the coefficient on treated $\times$ lanham and its standard error (in parentheses), which is adjusted for state-level clustering. Results presented in column (1) come from the 1970 Census; those in column (2) are from the 1980 Census; and those in column (3) are from the 1990 Census. The other Lanham Act categories include controls for state-level expenditures on schools and recreation (i.e., separate controls interacted with treated). The prereform state characteristics include the female employment rate, average female educational attainment (in years), the fraction black, and the fraction of individuals residing on farms. ***, **, and * indicate statistical significance at the 0.01 , 0.05 , and 0.10 levels, respectively. 
Table 11: DiD Estimates from the Placebo Reform

\begin{tabular}{lccc}
\hline Variable & $(\mathbf{1})$ & $\mathbf{( 2 )}$ & $\mathbf{( 3 )}$ \\
\hline treated $_{\mathrm{t}} \times$ lanham $_{\mathrm{s}}$ & $0.00023^{* * *}$ & $0.00021^{* * * *}$ & $0.00024 * * *$ \\
& $(0.00007)$ & $(0.00003)$ & $(0.00003)$ \\
& & & \\
placebo $_{\mathrm{t}} \times$ lanham $_{\mathrm{s}}$ & 0.00004 & 0.00004 & 0.00002 \\
& $(0.00005)$ & $(0.00003)$ & $(0.00001)$ \\
Census sample & & & \\
Treated cohorts' age range & 24 to 39 & 34 to 49 & 44 to 59 \\
Placebo cohorts' age range & 20 to 21 & 30 to 31 & 40 to 41 \\
Comparison cohort's age & 19 & 29 & 39 \\
\hline
\end{tabular}

Source: Author's analysis of the 1970, 1980, and 1990 U.S. Decennial Census (IPUMS)

Notes: Displayed in each cell is the coefficient on treated $\times$ lanham and placebo $\times$ lanham and they standard errors (in parentheses), which are adjusted for state-level clustering. Results presented in column (1) come from the 1970 Census; those in column (2) are from the 1980 Census; and those in column (3) are from the 1990 Census. All models include the full set of demographic controls, state-of-birth fixed effects, and the state-level Armed Services mobilization rate (interacted with treated) $* * *, * *$, and * indicate statistical significance at the $0.01,0.05$, and 0.10 levels, respectively. 